\title{
MÛ́VÉSZI REKLÁMOK DIMENZIÓINAK ÉS HATÁSOSSÁGÁNAK VIZSGÁLATA
}

\author{
BALÁZS KATALIN - BARKÓ MÁRIA
}

\author{
Debreceni Egyetem, Pszichológiai Intézet \\ E-mail: balazs.katalin@arts.unideb.hu
}

Beérkezett: 2015. február 12. - Elfogadva: 2016. január 15.

Háttér és célok: A tanulmány fơ célja a müvészi reklámok empirikus vizsgálata. Konkrétabban a múvészi reklámok, illetve a szakirodalmi források és fogyasztói értékelések alapján feltárt tényezôiknek hatékonyságvizsgálata.

Módszer: Fókuszcsoportos interjúk $(N=6)$ és kérdőives elốvizsgálatok $(N=47$, illetve $N=43)$ alapozták meg a kérdốives fỡvizsgálatot. Az elôvizsgálatok célja a fogyasztók által müvészinek tekintett reklámingerek gyüjtése és a müvészi reklám fogyasztói megítélésével kapcsolatos adatok gyüjtése; a releváns konstruktumok köznyelvi megnevezésének vizsgálata; illetve az ingerszelekció volt. Mindkét kérdốives vizsgálatban 27 reklámot itéltek meg a résztvevốk. A fốvizsgálat online, kérdôives formában zajlott. A vizsgálati személyek ( $N=117) 19$ reklámot értékeltek hatásosság szempontjából (tetszés, figyelemfelkeltố jelleg, hatásosság), illetve leiró jellemzók mentén (érthetôség, újszerüség, kerativitás, esztétikai érték, múvészi jelleg). A fớvizsgálatban a reklámok felidézését is vizsgáltuk. A vizsgálati személyek meggyoózési tudatosságát is felmértük.

Eredmények: Az empirikus adatok alapján a müvészi reklámok meghatározó hatásdimenziói az újszerüség, az esztétikai érték, ugyanakkor az érthetôségnek is van szerepe a múvészi reklámok hatásosságában. Ezekhez képest a kreativitás nem segíti tovább a müvészi megitélés elörejelzését. A reklámok múvészi jellege, illetve a hatásdimenziók nagyban meghatározzák a hatás mérésére szolgáló tetszés, figyelemfelkeltés és hatásosság megitélését, de a reklámfelidézést nem. Továbbá az adatok alapján a hatásosságot a személy meggyózési tudatosságának mértéke nem befolyásolja jelentôsen.

Konklúzió: Az empirikus adatok támogatják a müvészi megjelenitési mód alkalmazását a reklámokban. Ugyanakkor a müvészi megitélést döntôen meghatározó tényezók a reklám újszerüsége és esztétikai értéke.

Kulcsszavak: múvészi reklám, reklámhatásosság, újszerüség, esztétikai érték, kreativitás, meggyốzési tudatosság 


\section{BEVEZETÉS}

A tanulmány fố célja a nyomtatott formátumú múvészi reklámok hatáselemeinek empirikus vizsgálata. A múvészi jelleg, illetve az azt meghatározó elemek hatását vizsgáljuk, nem a vásárlásra vonatkozóan, hanem közvetett hatáselemeket figyelembe véve.

A téma gyakorlati jelentôsége napjaink fokozott reklámterhelésében keresendô. Az információelmélet a fogyasztókat érô nagyszámú reklámimpulzus miatt zavar- és zajforrásként tekint a reklámokra (Cho és Cheon, 2004; Speck és Elliott, 1997). Ezen túlterhelés hatására a fogyasztókban kialakult egy aktív reklámelkerülési reakció, ingerküszöbük megemelkedett, és a reklámok üzenete nehezen jut el hozzájuk (Cho és Cheon, 2004; Sas, 2006; Speck és Elliott, 1997). Speck és Elliott (1997) pedig úgy véli, hogy a különbözô médiumok közül a print reklámok esetében a legkisebb az elkerülési reakció, és a nyomtatott sajtóban megjelenó reklámok megítélése az egyik legerôsebb prediktora a reklámkerülés mértékének.

A reklámkerülés csökkentésének egyik lehetséges módja, hogy a hirdetôk gyakran a kevésbé motivált befogadókhoz illeszkedô perifériás meggyőzés stratégiáját követik, és egyszerúen a reklámok elemein keresztül pozitív érzéseket, kedvezô benyomásokat társítanak a termékhez, a reklámüzenethez (Obermiller és Sawyer, 2011). Ez a stratégia hatékony lehet, hiszen a kedvelt reklámok esetében az eladási mutatók magasabbak, mint a kevésbé kedvelt reklámok esetén (Haley és Baldinger, 2000). Bár pusztán a reklámok nem feltétlenül eredményeznek pénzben kifejezett vásárlóerôt, hanem a vásárlási hajlandóságot növelik (Veerkumar és Jaiswal, 2015). A kellemes érzések kiváltásának számos módja létezik (mint pl. humor vagy kreativitás), az általunk vizsgálni kívánt múvészi jelleg csak egy a kínálkozó stratégiák közül.

A mûvészi reklámok hatására vonatkozó ismeretek nagy része a múvészetpszichológiából, azon belül is az esztétikai értékre, annak megítélésére fókuszáló vizsgálatokból; illetve a marketingmegközelítésû kreativitásvizsgálatokból fakad. A múvészi reklámok egy-egy specifikus csoportját vizsgáló tanulmányok alapján feltételezhetô, hogy a múvészi reklámok kétféleképpen képesek elérni a termék iránti pozitív attitûd kialakítását. Egyrészt aktiválhatják a múvészetekkel kapcsolatos már meglévô pozitív attitúdöket, kognitív tartalmakat (Hagtvedt és Patrick, 2008; Halász, 2006; Hetsroni és Tukachinsky, 2005; Huettl és Gierl, 2012). Másrészt úgy is hathatnak a múvészi reklámok, hogy a kivitelezés során esztétikai értékkel bíró megjelenítési módokat alkalmaznak (pl. Reinartz és Saffert, 2013; West, Caruana és Leelapanyalert, 2013), pozitív élményekben részesítve a fogyasztót.

Ugyanakkor a tanulmányok gyakran a múvészi reklámok egy-egy szúk körére vonatkozóan vizsgálják a múvészi reklámok hatásosságát; és hiányosak az ismereteink arról is, hogy mely jellemzôk határozzák meg az észlelt múvészi értéket.

Jelen tanulmány célja a reklámok fogyasztók által megítélt múvészi jellege és annak hatáselemei (újszerúség, esztétikai érték) által kiváltott hatás (szubjektíven megítélt figyelemfelkeltố jelleg, szubjektíven megítélt hatásosság, a reklámok tetszése, illetve reklámok felidézése) empirikus vizsgálata nyomtatott reklámok esetében. A vizsgálatunkban fokozott hangsúlyt fektetünk a fogyasztói megközelítés figyelembevételére, amit számos publikáció szorgalmaz (pl. Hagtvedt és Patrick, 2008). 


\section{MÜVÉSZI REKLÁMOK}

Hagtvedt és Patrick (2008) definíciója alapján a múvészi reklámok olyan reklámok, amelyeknek a fogyasztó múvészi jelleget tulajdonít. A múvészi érték megjelenése a reklámokban azért lehet elônyös, mert Halász (2006) szerint a múvészetek lelki alapszükségletre felelnek. A fogyasztó a reklám befogadása közben gyakorta esztétikai élményt él át. Továbbá a múvészi reklámok többségében a reklámötlet és a hirdetni kívánt termék kapcsolatának felismerése, aha-élményhez vezethet (Auble, Frans és Soraci, 1979). Az 1. ábrán egy példa látható általunk múvészi reklámként tekintett hirdetésre.

A továbbiakban hivatkozott szakirodalmi források és fókuszcsoportos elôvizsgálat alapján a múvészi reklámoknak három fơ csoportját különböztetjük meg: reklámok, melyekben múvészi alkotások szerepelnek; reklámok, melyek esztétikai értékkel bírnak; illetve kreatív reklámok, amelyeket az üzenet átadásának módja tesz múvészivé. A vizsgálatban az utóbbi két csoportba sorolható reklámokat használtunk ingerként.

\section{A reklámokban szerepló múvészi alkotások hatása}

A múvészi reklámok múködése értelmezhetô a Reklámválasz Modell alapján is (továbbiakban: ARM [advertising response modelling], Mehta és Purvis, 1994). A szerzók Petty és Caccioppo Feldolgozás Valószínûségi Modelljébôl indulnak ki (Elaboration Likelihood Model, ELM, Petty és Caccioppo, 1981, 1986). Az eredeti modell a meg-

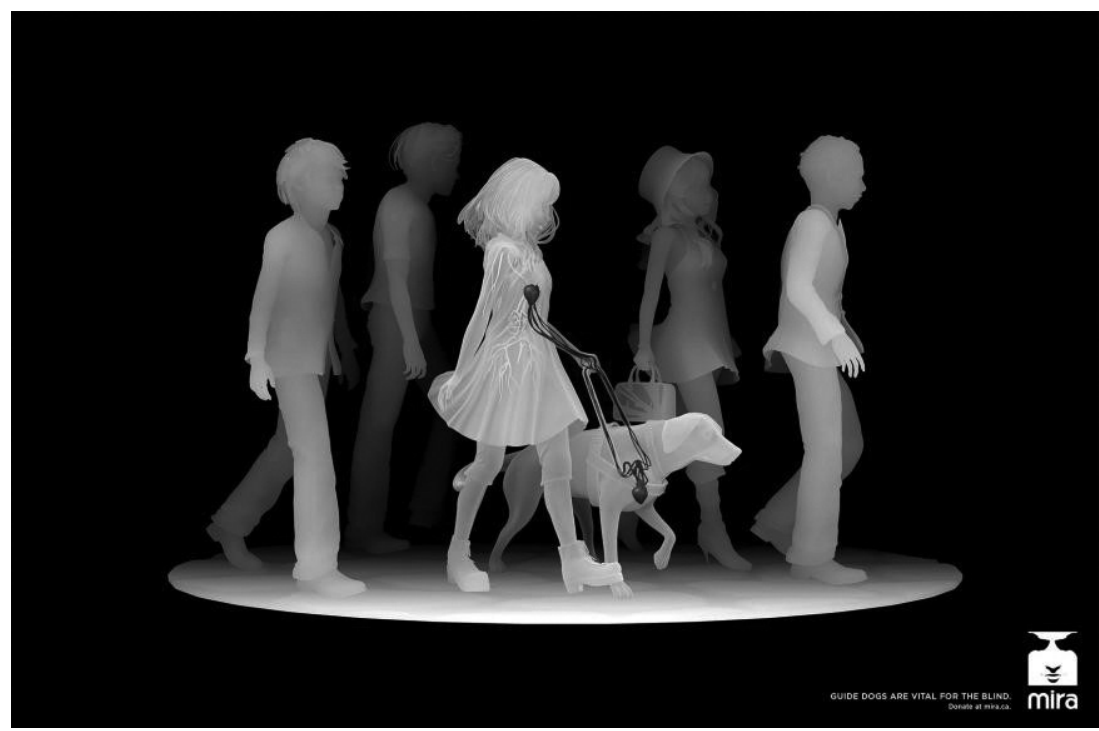

1. ábra. A reklám szövege: A vakvezetố kutyák létfontosságúak a vakok számára. Adományozzon a mira.ca részére (forrás: http://adsoftheworld.com/media/print/mira_ guide_dog_association_girl) 
győző közlés feldolgozásának elmélyült és felszínes módját különböztette meg, és arra vonatkozó információt szolgáltat, hogy az egyes információfeldolgozási utak esetén milyen jellegú üzenetek hatékonyak. Az ARM megtartja az eredeti modell centrális-periferiális felosztását, ugyanakkor ebben a modellben a centrális-periferiális feldolgozási mód az attitúd tárgya szerint különül el: a centrális út a márkára vonatkozó attitúdöket és értékelést határozza meg; míg a perifériás út magával a reklámmal kapcsolatos attitûdöket, annak kedvelésére vonatkozó ítéletet határozza meg, és közvetve hat a márkára vonatkozó attitúdre. Együttes hatásuk révén alakul ki a vásárlási szándék.

A reklám kognitív feldolgozása csak akkor megy végbe, ha képes felkelteni a fogyasztó figyelmét. Ha megtörtént a figyelem felkeltése, akkor a reklám feldolgozása egyik vagy párhuzamosan mindkét úton végbemegy, és megkezdődik a reklám által kommunikált meggyôzésre szánt üzenetek feldolgozása. A centrális út esetében a termékkel, illetve a márkával kapcsolatos információ van a középpontban, míg a perifériás úton a reklámmal, annak kivitelezésével kapcsolatos információ. A múvészi reklámok hatása a perifériás meggyôzési úton jut jelentôs szerephez, mivel a hangsúly a kivitelezés módján van. Mindkét modell alapján ezeknek az elemeknek inkább alacsony involváltság esetében van hatása, és hatásuk rövid távú. Továbbá Mehta és Purvis (1994) szerint ezt a sokrétû folyamatot nem lehet a hatás egyetlen mérôeszközével megragadni, hanem több mérôeszközt szükséges használnunk a hatásosság mérésére.

Hagtvedt és Patrick (2008) specifikus modellje magyarázatot kínál a múvészi alkotások reklámokban való szerepeltetésének fogyasztókra gyakorolt hatására. Az általuk létrehozott „múvészi transzfer” (art infusion) nevú modell azon alapul, hogy a múvészetek pozitív jelentéstartalommal bírnak az emberek számára, ezért a múvészeti alkotások termékhez való társítása kedvezôen befolyásolja a termék, illetve a márka értékelését. A szerzốk szerint ez egy általános pozitív hatás, ami az emberek múvészetekre vonatkozó általános sémájából fakad (Joy és Sherry, 2003).

Ezt megerôsíti Hetsroni és Tukachinsky (2005), kutatási eredményeik alapján a fogyasztók azokat a reklámokat kedvelik leginkább, amelyek tipikusak, klasszikusnak mondhatók. A gyakorlat igazodik ehhez: a szerzôk által átnézett reklámok 65\%-ában olyan múvészi alkotások szerepeltek, amelyeket reneszánsz, klasszikus vagy romantikus stílusban alkottak, és amelyeket a legtöbb ember tipikusan a múvészetekkel kapcsol össze.

Huettl és Gierl (2012) vizsgálatának eredményei tovább árnyalják a képet. Kísérleti elrendezésükben a termékeket múalkotásokkal, illetve múvészi alkotásokra nagyon hasonlító fényképekkel szerepeltették. Azt találták, hogy a múalkotások ismertségtôl és stílusirányzattól függetlenül is hatással voltak a hirdetésekben a vásárlási szándékra. A Hagtvedt és Patrick (2008) által feltételezett luxussal kapcsolatos észleletek aktiválódtak, ugyanakkor a magas árral kapcsolatos elképzelések is. Az adatok arra utalnak, hogy a múalkotás termékhez történố társítása akkor befolyásolta elônyösen a vásárlási szándékot, azaz akkor volt hatásos, ha a terméket hedonikusként pozicionálták és volt információ az árról; míg funkcionális termékek esetében nem volt hatása. Ha nem állt rendelkezésre árral kapcsolatos információ, akkor kisebb hajlandóságot fejeztek ki a termék megvásárlására vonatkozóan, és ez a negatív hatás a funkcionális termékeknél még jobban érvényre jutott. A szerzôk szerint ezek alapján a múvészi transzfer jelensége nem tekinthetố általános pozitív hatásnak. 
Hagtvedt, Hagtvedt és Patrick (2008) múalkotásokat ítéltetett meg laikus vizsgálati személyekkel. Azt találták, hogy a múvészi alkotások összegzô megítélésének kiindulási alapja az érzelmi megítélés (arousal-szint és valencia), a mediátor változók pedig négy faktorba rendezôdtek, melyek két különálló vonalon hatnak az összegzó értékelésre (az általuk illesztett SEM-modell szerint). Az egyik mediátor út az esztétikai érték, kiegyensúlyozottság; míg a másik a kíváncsiságot kiváltó, kreatív, újszerú jellemzôk által meghatározott út. Ez a múvészi ingerekre vonatkozó eredmény összhangban van azzal a feltételezésünkkel, hogy a múvészi reklámok megítélését az újszerúség és az esztétikai érték határozza meg.

Az általunk vizsgálni kívánt múvészi reklámok esetében a múvészi megközelítés nem öncélú, hanem a koncepció részét képezi, viszont nem szerepelnek múalkotások a reklámokban, ez jelentôs különbség a korábbi vizsgálatokhoz képest, melyek a múvészi reklámok vizsgálatát célozták. Ugyanakkor, mivel számos esetben a funkcionális és hedonisztikus termékek szétválasztása nehézkes, hiszen vannak funkcionálisnak beállított hedonisztikus vásárlások (pl. autóvásárlás, lásd pl. Törôcsik, 2007, 19), így ezek elkülönítésére a vizsgálatban nem törekszünk. Mindenesetre a múvészi jelleg pozitív hatását várjuk.

\section{Az esztétikusság}

A múvészi reklámok alapvetô jellemzője az esztétikusság, ami alatt a globális megítélést értjük. Jelen tanulmányban az esztétikusság megfogalmazást a globális megítélésre értjük, esztétikai értéket pedig ennek szúkebb aspektusára: a szépségre, a vizuális megjelenítésre.

Számos modell létezik a múvészetpszichológiában az esztétikai ítélethozatalra vonatkozóan (bôvebben lásd Farkas, 2003), ezek közül kiemelkedik két modell: Berlyne (1971) és Martindale és munkatársainak (pl. Martindale, Moore és Borkum, 1990; Martindale, Moore és West, 1997) modelljei. Berlyne (1971, 1994) szerint az esztétikai ítéletet az inger kollatív jellemzői befolyásolják elsôdlegesen, mint az újszerúség vagy a komplexitás. Martindale és munkatársai (pl. Martindale és mtsai, 1990, 1997) szerint pedig az ökológiai változók a meghatározóak, mint például a (proto)tipikusság és jelentésteliség. Az újszerúséget gyakran definiálják úgy, mint a szokásostól vagy tipikustól eltérôt (pl. Burroughs, Moreau és Mick, 2008). Azaz a két legismertebb modell (Hoegg és Alba, 2008) ellentmond egymásnak.

Whitfield (2000) modellje, az integratív modellek egyike, amely szerint az esztétikai ítélet attól függ, hogy a befogadó számára az inger mely jellemzôi lesznek szembetûnốek. Ha a befogadó számára az inger jelentéstelisége dominál, akkor az esztétikai ítélet Martindale és munkatársainak modellje (1990) szerint alakul; ha pedig az inger tulajdonságai, jellemzôi a kiugróak, akkor a Berlyne-modell által bejósolt módon alakul az esztétikai ítélet.

Hekkert, Snelders és van Wieringen (2003) másképp integrálja a két eredeti, ellentmondásos elképzelést. Bár jórészt érvényesnek tartják a Whitfield-modell téziseit, szerintük az esztétikai ítélet egy kéttényezôs információfeldolgozási rendszer múködési sajátosságának eredménye, amelynek elemei képesek időnként egymás ellenében is 
múködni. A két tényezô közül az egyik komponens egy automatikus folyamat, ami a prototipikusságra érzékeny, míg egy másik folyamat tudatosabb módon zajlik, ahol az újszerúség a mérvadó. A rendszer múködése pedig kontextuális tényezôktôl függ (pl. jártasság).

Az esztétikai ítélettel foglalkozó tanulmányok alapján az esztétikai ítéletet tekintve az újszerúség és/vagy a prototipikusság fontos szerephez jut. Felmerül azonban a kérdés, hogy tekinthetô-e a két kontstruktum egy dimenzió két végpontjaként, mint például Burroughs és munkatársai (2008) esetében, vagy ha mégsem egymás ellenpólusai, akkor melyiknek meghatározóbb a szerepe a megítélésre vonatkozóan. Berlyne (1971) szerint az újszerúség a meghatározóbb; Martindale és munkatársai (1990, 1997) szerint a prototipikusság; míg Whitfield (2000) vagy Hekkert és munkatársai (2003) szerint ez kontextuális tényezôktôl függ. További nyitott kérdés a kapcsolat jellege is: lineáris-e a kapcsolat jellege, ahogy azt Martindale és munkatársai (1990) kifejezték, vagy nem-lineáris, ahogy azt Berlyne (1971) hitte.

\section{A kreativitás és múvészi jelleg}

A múvészi reklámok természetérôl való közvetett ismeretek másik forrását azok a tanulmányok jelentik, amelyek megítélésünk szerint múvészi értékkel bíró, deklaráltan kreatív reklámokat használtak fel ingerként. A kreativitás szakirodalmában a múvészi vonatkozások nem tipikusan, de említésre kerülnek. Továbbá a kreativitással és kreatív reklámokkal foglalkozó tanulmányokban az újszerúség fogalma gyakran megjelenik, mint kulcsfontosságú elem.

Burroughs és munkatársai (2008) szerint a kreativitás egy háromdimenziós konstruktum, amelynek aldimenziói az újszerúség, a funkcionalitás és az esztétikum. Az újszerúséget a következóképpen definiálták: mennyire tér el a tipikustól vagy hagyományostól. A funkcionalitás dimenziója azt jelöli, hogy a kimenet mennyire hasznosítható, konstruktív. Szerintük az esztétikai dimenzió nem feltétlenül jelenik meg minden esetben, ám ha a kreativitásnak múvészibb vagy kifejezóbb célja van, akkor ez a dimenzió mindenképp jelen van. Ekkor a kimenet „nem csak hogy szokatlan, de bizonyos szépséget, eleganciát vagy vonzóságot mutat" (Burroughs és mtsai, 2008, 1015). Sasser, Koslow és Kilgour (2013) szerint a kreativitás magában foglalja az originalitást és a megfelelóséget, utóbbi fogalomban fontosnak tartják a stratégiai és múvészi szempontokat is. Elóbbi tényezốt pedig az elfogadott normától való eltérésként definiálták.

Reinartz és Saffert (2013) a Torrance-féle többdimenziós kreativitásfogalomból kiindulva a következô dimenziók mentén mérte a reklámok kreativitását: originalitás, flexibilitás, elaboráció, szintézis és müvészi érték. Utóbbi dimenzió alatt magas szintû múvészi kreativitást és esztétikai szempontból vonzó elemeket értettek. Lehnert, Till és Carlson (2013) szerint a kreatív reklámok divergensek, és többek között újszerú és esztétikus megjelenésú elemeket tartalmaznak. Cropley és Cropley (2011) másként értelmezi a kreativitás és az esztétikum viszonyát: szerintük a kreativitás az esztétikum egy különleges esete: a szépség szükséges eleme a kreativitásnak, de „nem minden kreatív, ami szép. A kreativitás meghaladja a "puszta « szépséget, hiszen magában foglalja az újszerúséget és a hatásosságot” (Cropley és Cropley, 2011, 24). 
West és munkatársai (2013) szerint a reklámversenyek a kreativitás kiemelkedô mérföldkövei. Reinartz és Saffert (2013) eredményei szerint a kreatív reklámok hatásosabbak, jobban kedvelik óket. Kiemelik továbbá, hogy az egyes kreativitásdimenziók eltérô hatásúak, és a hatásdimenziók ötvözése tovább növeli a reklámok hatásosságát. Vizsgálatukban az egyik leghatásosabb az originalitás és múvészi érték kombinációja volt.

Phillips (2003) arról számol be, hogy a nagyon újszerú üzenetet megfogalmazó kreatív reklámok megértése nehéz, ami ront a reklám hatásosságán. Emiatt azok a reklámok tûnnek hatékonynak, amelyeknek megértése nem okoz nagy nehézséget, de elégséges mentális kihívást jelent az aha-élmény (Auble és mtsai, 1979) kiváltásához.

A kreatív reklámok tehát újszerüek, funkcionálisak, és időnként esztétikusak. A kreatív reklámok egy része is múvészinek tekinthetô. Viszont míg a múvészi reklámok központi eleme az esztétikai érték, az nem alapvetô eleme a kreatív reklámoknak. A kreatív reklámok esetében, ahogy az Burroughs és munkatársai (2008) definíciójában is láthattuk, az újszerúség meghatározóbb érték. Mivel azonban számos forrás említést tesz az esztétikai értékrôl és a múvészi jellegrôl a kreativitással összefüggésben, éppen ezért vizsgálatunkban feltételezzük, hogy a kreatív reklámoknak sok esetben az újszerúségük és esztétikusságuk miatt múvészi értéket is tulajdonítanak a fogyasztók. Továbbá feltételezzük, hogy az érthetôség is szerepet játszik a múvészi reklámok hatásosságában.

\section{A reklámok hatékonyságának mérése}

Ahogy azt korábban kifejeztük, ebben a tanulmányban nem a vásárlási viselkedésre vonatkozó hatásosság vizsgálatára, hanem közvetett hatáselemek vizsgálatára kerül sor. A közvetett hatáselemek vizsgálatát mind a pszichológia, mind a marketing területén elfogadott modellek indokolják, melyek a viselkedés iránti attitúd és a viselkedés (Tervezett Viselkedés Elmélete, Ajzen, 1991; Fishbein és Ajzen, 2000), illetve a vásárlási szándék és a vásárlás közötti összefüggést magukban foglalják (Reklámválasz Modell, Mehta és Purvis, 1994). A modellek alapján a meggyôzó közlés vagy reklám hatása számos mediáló tényezôn keresztül érvényesül a viselkedésre vonatkozóan. A Reklámválasz Modell alapján a reklám megítélése is befolyásolja a viselkedési szándékot. Az általunk vizsgálni kívánt tényezôk, mint szubjektíven megítélt figyelemfelkeltô jelleg, szubjektíven megítélt hatásosság, és a reklámok tetszése a reklám megítélésének különbözô dimenzióinak tekinthetôk.

Mehta és Purvis (1994) a hatásosság következő mérőeszközeit veti fel: az emlékezeti bevésôdés, felismerési vagy felidézési teljesítmény, a márka értékelése, a reklám kedvelése, a vásárlási szándék, valamint a hirdetett termékkel vagy a reklám kivitelezésével kapcsolatos diagnosztikus eszközök. Továbbá, mivel a reklám fontos feladata, hogy áttörjön a reklámzajon és felkeltse a figyelmet, ezért a figyelemfelkeltô képesség is a hatásosság egyik mérôeszköze.

A reklámok hatásának egy objektív méróeszköze az emlékezeti teljesítmény mérése. Ennek számos formája ismert, például a vizsgálati személynek fel kell ismernie a korábban bemutatott reklámokat, vagy fel kell idéznie azokat (támpont segítségével vagy enélkül). Till és Baack (2005) azt találta, hogy a kreatív reklámok elônye a szabadfelidézéses helyzetben mutatkozik meg. 
A Feldolgozási Valószínúségi Modellt tekintetbe véve (Petty és Caccioppo, 1981, 1986) a figyelemfelkeltô képesség egy alapvetô kritérium a reklámhatásossághoz: ha a figyelem nem alakul ki, akkor a feldolgozás nem megy végbe. A szubjektíven megítélt hatásosság a befogadásélményt ragadja meg, míg a tetszés a globális megítélést. A felidézés pedig egy objektívebb mérése lehet a hosszabb távú hatásnak.

A múvészi reklámok, melyek vagy tartalmaznak múvészi alkotást, vagy alkalmaznak múvészi hatáseszközöket, megítélésünk szerint kiemelkednek a reklámok tömegébôl és fokozott figyelmet váltanak ki. Feltételezzük, hogy ha a befogadó figyelme a múvészi reklámra irányul, akkor annak esztétikussága révén pozitív élményeket él át, gyenge arousal-szint mellett. Ha a reklám kreatív, akkor az arousal-szint növekedés feltehetốen nagyobb, az aha-élmény révén. Gyakran azonban a befogadó nem érti meg a kreatív reklámot, így a hatás gyengébb vagy elmarad (Philips, 2003). A reklám befogadásélménye meghatározó lehet a reklám megítélésére vonatkozóan.

Haley és Baldinger (2000), valamint Mehta és Purvis (1994) is hangsúlyozzák: mivel a reklámok több szinten is befolyást gyakorolnak a fogyasztóra, így a hatás méréséhez is érdemes több mérôeszközt felhasználni.

Jelen vizsgálatban a reklám hatásosságát a reklám befogadásának különbözô szakaszaira vonatkozó szubjektív értékeléseivel mérjük: a befogadók által megítélt figyelemfelkeltô képességet és hatásosságot, valamint a reklámokra vonatkozó tetszést. Ezen felül mérjük még a reklámok emlékezetre gyakorolt hatását is a támpont nélküli felidézés segítségével, amit objektívebb hatásvizsgálati módszerként tartanak számon.

\section{A befogadó sajátosságainak szerepe a reklámok hatásosságában}

A reklámok kapcsán érdemes megemlíteni, hogy a fogyasztói szemlélet sokszor eltér a reklámszakemberek nézôpontjától, ami tulajdonképpen a laikus-szakértô különbség. A laikus-szakértô szemléletbeli különbségek a múvészetpszichológiában is dokumentáltak, miszerint a laikusok tulajdonképpen a hétköznapi érzékelési stratégiáikat használják a múvészi alkotások szemlélése során (Chupnik és Gebotys, 1997). Talán ezért sem válik el esztétikai ítélethozataluk során a prototipikusság és újszerúség megítélése, míg a szakértôknél ez inkább megfigyelhetô (Hekkert és mtsai, 2003). West, Kover és Caruana (2008) azt találták, hogy a kreativitást a fogyasztók másképp értelmezik, mint a szakemberek: a fogyasztók a reklámok kivitelezését is fontos szempontnak tartották. Ugyanakkor a laikusok számára az alacsonyabb fokú kreativitás elönyösebb, mint a szakértôknek, a megfelelố pozitív hatás kiváltásához (pl. Phillips, 2003). Számos tanulmányban megjelenik az igény, hogy a reklámvizsgálatok is jobban fókuszáljanak a hétköznapi fogyasztókra (pl. Dahlén, Rosengren és Törn, 2008; Hagtvedt és Patrick, 2008).

A reklámhatékonyság fogyasztói megítélésében szerepet játszhatnak a fogyasztók azon hiedelmei is, amelyek a kereskedelemmel, eladással, illetve reklámozással kapcsolatosak, ezek összegzôdnek a meggyózési tudatosságban. A meggyôzési tudatosságot úgy képzelhetjük el, mint sémák és hiedelmek rendszerét az értékesítôk taktikáira vonatkozóan, amelyek segítségével a fogyasztók azonosítják a meggyốzési helyzeteket, következtetéseket vonnak le az üzenetet meghatározó háttérben álló okokról, becslé- 
seket tesznek a különbözô válaszviselkedések következményekre vonatkozóan és saját céljaiknak megfelelố viselkedéses válaszokat hoznak létre (Friestad és Wright, 1994; Kirmani és Zhu, 2007).

A meggyózési tudatosság a mentalizáció, azaz szándéktulajdonításra épülve alakul ki, a hétköznapi tapasztalatok során fejlôdik, felnôttkorra éri el az optimumát, majd idôs korban a mentális képességek hanyatlásával párhuzamosan csökken (Campbell és Kirmani, 2008; Hardesty, Bearden és Carlson, 2005; McAlister és Cornwell, 2009; Wright, Friestad és Boush, 2005).

Guo és Main (2014) szerint vannak kulturális különbségek a meggyôzési tudatosságban. Összefoglaló tanulmányuk szerint a kulturális önmeghatározásnak (független vagy személyek közötti) hatása van arra, hogyan viselkednek a személyek eladási helyzetben. A meggyózési tudatosság aktiválódása általában felkelti a fogyasztóban azt a gyanút, hogy a hirdetônek vagy értékesítőnek valamiféle hátsó szándéka van, ami miatt szkeptikussá válhat ilyen helyzetekben, és jobban ellenáll a meggyôzési kísérleteknek (pl. Kirmani és Zhu, 2007). Kirmani és Zhu (2007) azt találták, hogy a személyek, akik inkább a veszteségek elkerülésére törekednek, nyílt manipulációnál meggyôzési tudatosságukat jobban aktivizálják, s az a márkaértékelésre is hatást gyakorol.

Bearden, Hardesty és Rose (2001) szintén megállapítja, hogy akiknek a meggyôzési tudatossága nagyobb, azokat nehezebb meggyôzni. A szerzók által kialakított Fogyasztói magabiztosság kérdôív (Bearden és mtsai, 2001) hat itembôl álló alskálája a Meggyőzési tudatosság skála. Úgy vélik, hogy a meggyôzési tudatosság szerepet játszik a mindennapi meggyôzési helyzetekben, így például abban is, hogy mely reklámokat tartják szimpatikusnak a befogadók.

A fentiek alapján a személy reklámok területén való jártassága, illetve a meggyôzési tudatossága is szerepet játszhat abban, hogy hogyan ítéli meg a reklámokat. Jelen vizsgálatban mindezekról gyújtünk információt.

\section{VIZSGÁLAT}

Az empirikus vizsgálat célja a reklámok múvészi megítélését meghatározó dimenziók és a múvészi reklámok hatásosságának vizsgálata. A szakirodalom alapján a reklámok múvészi jellegét potenciálisan meghatározza a reklám újszerúsége, esztétikai értéke, érthetôsége. Alapvetôen ezeket a jellemzóket vesszük figyelembe. Ugyanakkor a kreativitás múvészi megítélésre vonatkozó hatását is vizsgáljuk. A konstruktumok operacionalizálását két elôvizsgálat keretén belül pontosítottuk, hogy a vizsgálatban a köznyelvben használt megfelelőjüket alkalmazzuk. A reklámingerek szintén elôvizsgálat keretén belül kerültek kiválasztása. A reklámok hatásosságának mérése a Haley és Baldinger (2000), valamint Mehta és Purvis (1994) által meghatározott dimenziók egy része mentén történt. Ezek a dimenziók a figyelemfelkeltô képesség, tetszés, szubjektíven megítélt hatásosság mértéke és felidézés voltak.

A tervezett vizsgálat újszerúsége abban áll, hogy reklámok esetén célozza feltárni a fogyasztók reklámokra vonatkozó múvészi értékítéletének komponenseit. A múvészetpszichológiában leginkább a klasszikus értelemben vett múvészi alkotások esetén történik meg a múvészi érték befogadásának vizsgálata Ugyanakkor a múvészi reklámo- 
kat tágabban értelmezzük, mint múvészi alkotásokat megjelenítô reklámokat: múvészi kifejezôeszközöket vagy kreatív megközelítéseket alkalmazó reklámokat is a múvészi reklámok közé sorolunk, s ezeket vizsgáljuk.

\section{Hipotézisek}

A szakirodalom alapján az esztétikai érték (lásd pl. Benesch, 1994; Halász, 2006) és az újszerúség is fontos szerepet játszik a múvészi alkotások megítélésében, az esztétikai értékítélet meghozatalában (Berlyne, 1971, 1994; Hagtvedt és mtsai, 2008; Hekkert és mtsai, 2003; Whitfield, 2000). A reklámok múvészi megítélését valószínúleg hasonlóképpen meghatározza a reklámok esztétikai értéke (Hagtvedt és mtsai, 2008). Ugyanakkor a reklámok újszerúsége is befolyással lehet a múvészi megítélésre, mint ahogyan a preferenciaítéletekre is hatással van (pl. Berlyne, 1971). Ebbôl következóen feltételezzük:

H1: A reklámok müvészi értékitélete (mennyire tartják múvészinek) összefügg a reklám esztétikai értékének (mennyire szép) és újszerüségének megitélésével.

A reklám esztétikai értéke és újszerúsége a múvészi alkotások értékelésére is hatással lehet (pl. Hagtvedt és mtsai, 2008), így feltételezhetô, hogy képes lehet befolyásolni a múvészi reklámok hatékonyságát is. Ugyanakkor a fokozott újszerúség az érthetôség rovására mehet, rontva ezáltal a reklám megítélését (Philips, 2003). Mindezek alapján feltételezzük:

H2: A reklám müvészi értékelésének és az ezt meghatározó fóbb tényezóknek (esztétikai értékének, és újszerüségének megítélése) a reklám hatásosságának bejóslását segítik. És az érthetôség tovább javítja a reklámok hatásosságának bejóslását.

A hatásosságot a következó változókkal mérjük: szubjektíven megítélt figyelemfelkeltô jelleg, szubjektíven megítélt hatásosság, a reklámok tetszése, illetve a reklámok felidézése.

Aki hiszi, hogy a meggyôzési helyzetekben kiismeri magát, az valószínúleg ellenállóbbnak mutatkozik a reklámok által célzott meggyózési kísérletekkel szemben (Bearden és mtsai 2001; Kirmani és Zhu, 2007), ami ronthatja a reklámok megítélését.

H3: A nagyobb meggyôzési tudatosságú egyének alacsonyabbnak itélik a reklámok hatékonyságát. Különösképpen várjuk ezt a hatást a tetszés és a hatásosság szubjektív megítélésének tekintetében.

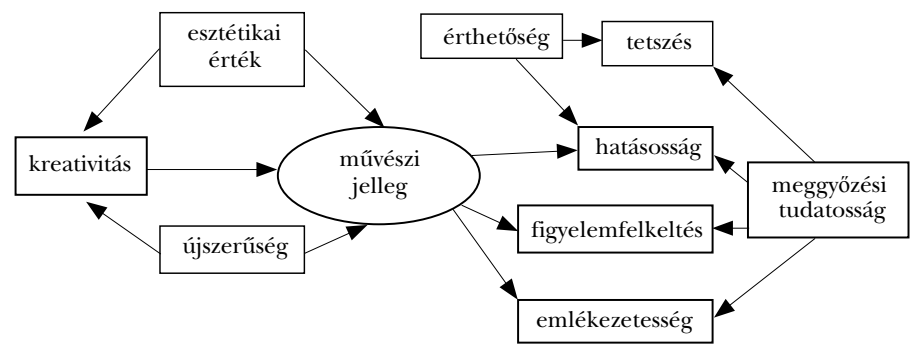

2. ábra. A hipotézisek alapján feltételezett kapcsolatok a változók között 
A kreativitásnak az újszerúség mellett lehet esztétikai vonatkozása is (Burroughs és mtsai, 2008).

H4: Az esztétikai értékelés (szépség megítélése és az újszerúség megitélése) a kreativitás megitélésével is összefügg. A kreativitás megitélése továbbá összefügg a reklámok múvészi jellegének megítélésével.

A hipotézisek alapján felvázolható változók közötti összefüggéseket a 2. ábra foglalja össze.

\section{Elövizsgálatok}

A fôvizsgálat végleges formája három elôvizsgálat segítségével került kialakításra. Az elôvizsgálatok célja a megfelelô ingeranyag kiválasztása és a konstruktumok vizsgálati személyek szóhasználatához idomuló megfogalmazása volt.

\section{Az ingeranyag kiválasztása}

Elsô lépésben pszichológushallgatókat ( $\mathrm{N}=6,18-22$ éves nôk) kértünk, hogy gyújtsenek általuk múvészinek ítélt nyomtatott reklámokat. Az általuk gyújtött reklámokat fókuszcsoportos keretben, több ülésben elemezték, hogy a konszenzusos megítélésük egyértelmú legyen. Ugyanakkor a fókuszcsoport keretén belül hétköznapi elméleteik is felszínre kerültek a múvészi reklám mibenlétérôl. A fókuszcsoportok során a hallgatók számos szempontot említettek meg, amelyekrôl azt vélték, hogy fontos elemei a múvészi reklámnak. Ezeket a következók:

1. Kivitelezés módja:

a) szépség: szép, múvészi eszköztár, kidolgozott, átgondolt, letisztult kompozíció;

b) újszerúség: szokatlan (perspektíva), meghökkentô, figyelemfelhívó, formabontó, kreatív, újszerú, ötletes;

c) szimbolikus jelleg: gondolkodni kell rajta, indirekt, sûrítettség, elvontság, átvitt értelem, kétértelmúség, kettôsség, mögöttes tartalmak, elvont tartalmakat tesz konkréttá.

2. Hatás: pl. aha-élmény megjelenése, humorosság, sokkoló jelleg.

3. Érthetôség: lényegkiemelő, a kép és a szöveg egymást kiegészítô, harmonikus, egyszerú-nagyszerú.

A fókuszcsoportok eredményeképpen gyújtött múvészi reklámok az ingeranyag alapját képezték. Mivel a kivitelezés esztétikai értéke és az újszerúség tûnnek a szakirodalom és a fókuszcsoportok alapján is a múvészi megítélés legjelentôsebb változóinak, ezért olyan ingeranyag összeállítását céloztuk, mely e két jellemzô mentén heterogén. A két változónak alacsony, közepes és magas értékét megkülönböztetve 3x3-as elrendezést alakítottunk ki. Minden cellába három reklámot választottunk, ami 27 reklámot eredményezett kiindulási ingeranyagként. A besorolást a két szerzô végezte, a fókuszcsoportban elhangzottakat figyelembe véve. A célja ennek a besorolásnak az volt, hogy ne pusztán nagyon újszerú és nagyon esztétikus reklámok kerüljenek az ingeranyagba, annak érdekében, hogy a két változó hatása a múvészi megítélésre mérhetô legyen. 
Mivel azonban a besorolás némileg szubjektív, a különbözô kategóriákba esést nem tekintjük független változónak az elemzések során.

Két további vizsgálatot végeztünk, hogy kvantitatív adatok segítségével ellenôrizzük a kutatási elrendezésnek való megfelelést, illetve hogy kiválaszthassuk a fôvizsgálatban használni kívánt ingeranyagot. Ezekben a vizsgálatokban szintén 27 reklámot kellett megítélniük a vizsgálati személyeknek a következő szempontok mentén: mennyire tartják újszerúnek (1), esztétikusnak (2), érthetônek (3), kreatívnak (4). Csak az elsô két szempontot vettük figyelembe az értékelésnél. A reklámok random sorrendben követték egymást. A visszajelzések alapján a kérdőív kitöltése 15-20 percig tartott. A vizsgálati minta 47 fô (40 nô és 7 férfi). Átlagéletkoruk 29,2 év (SD=10,4). Az eredmények alapján a végleges, fôvizsgálatban alkalmazott ingeranyagot úgy igyekeztünk összeállítani, hogy a vizsgálati elrendezés minden cellájában két-két reklám szerepeljen. Ez 18 reklámingert eredményezne összesen. Viszont az elôvizsgálat során nem volt olyan reklám, amelynek értékelése újszerúség szempontjából magas, esztétikai érték szempontjából alacsony lett volna, ezért döntöttünk a vizsgálat megismétlése mellett.

A következô elôvizsgálatban a kiválasztott ingereken felül az ingeranyag három korábban nem használt reklámmal egészült ki, mely reklámok, megítélésünk szerint a kérdéses designcellába tartoznak. A harmadik elôvizsgálatot 88 fố kezdte el kitölteni; a kérdőív kitöltését maradéktalanul 18 és 25 fó fejezte be. A vizsgálat mintája így a 43 fó (30 nô és 13 férfi). Átlagéletkoruk 29,3 év (SD=11,1). Bár az újabb elôvizsgálat segítségével sikerült heterogénebb ingeranyagot összeállítani, de az eredmények alapján közöttük is csak egy olyan reklám volt, amit a kitöltôk nagyon újszerûnek és kevéssé esztétikusnak ítéltek, így a végsố ingerkészlet 19 reklámot foglalt magában. A következô ábrákon (3-6. ábra) néhány példával kívánjuk szemléltetni, milyen reklámok kerültek bele a végsô ingeranyagba.

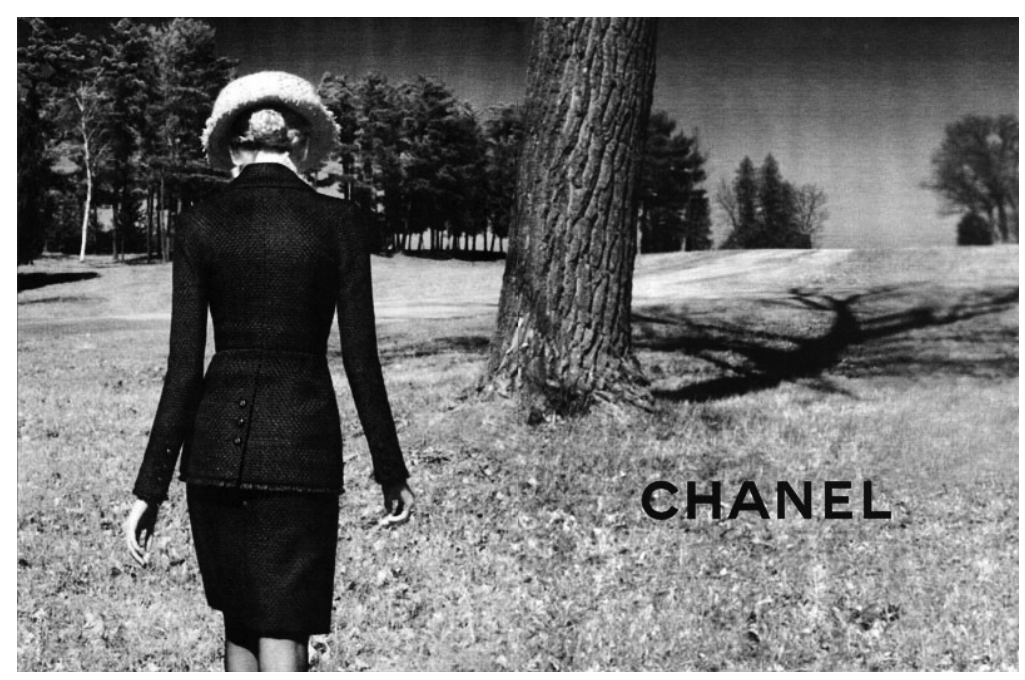

3. ábra. Példa kevéssé újszerû, magas esztétikai értékkel bíró reklámra (forrás: http://dresscodeemlyon.files.wordpress.com/2011/04/chanelaw0910ad01.jpg) 


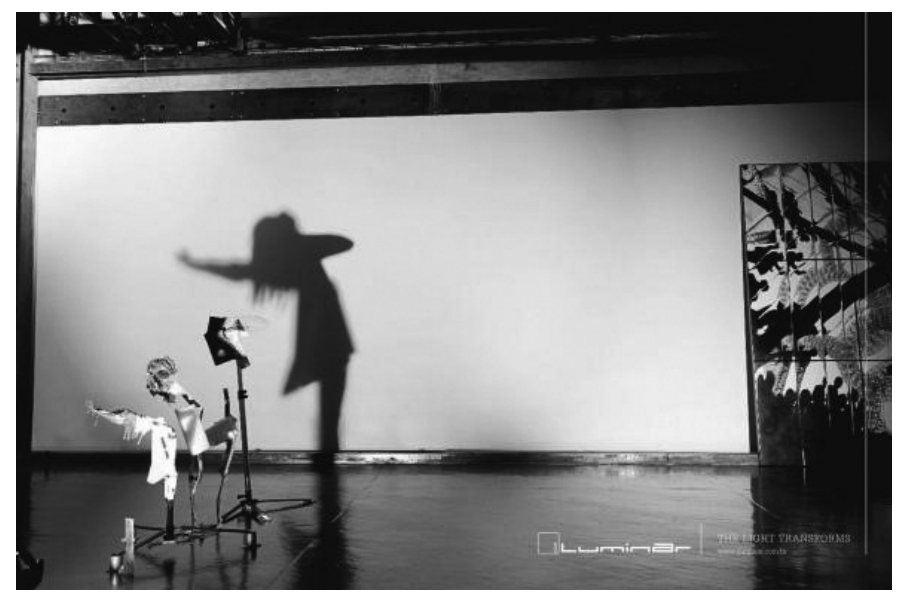

4. ábra. Példa nagyon újszerû, magas esztétikai értékkel bíró reklámra (szövege: Iluminar. A fény változtat, forrás: http://adsoftheworld.com/media/print/iluminar_ballerina)

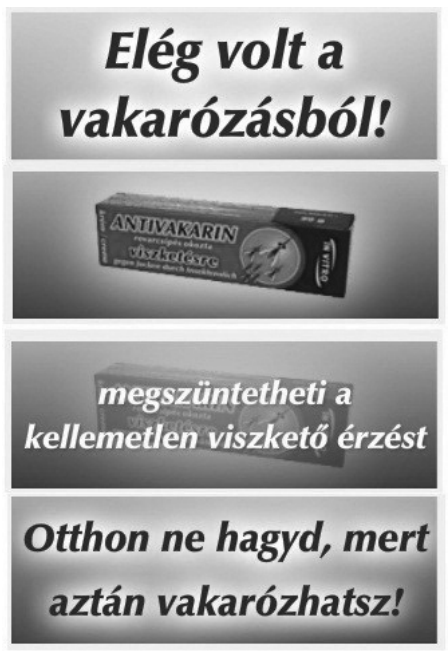

5. ábra. Példa kevéssé újszerû, kis esztétikai értékû reklámra

(forrás: https:/ /www.facebook.com/photo.php?fbid=478311462248313\&set=pb.443644602381666.-22075 20000.1373372020.\&type $=3 \&$ theater $)$ 


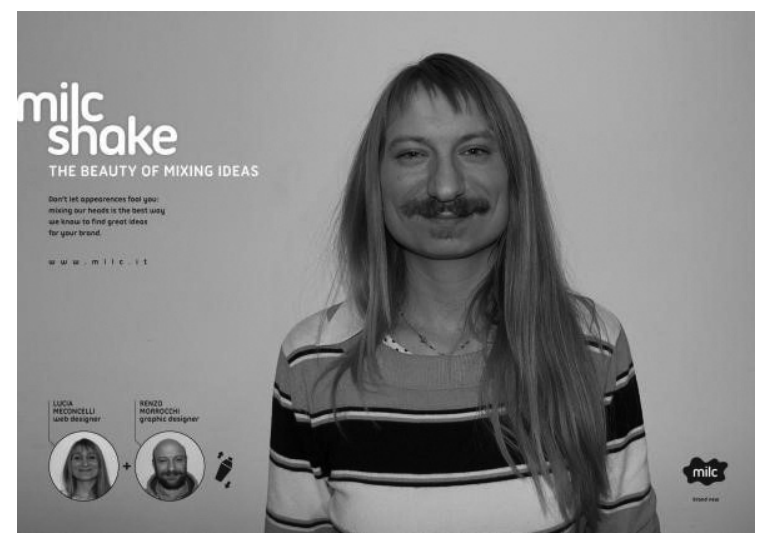

6. ábra. Példa nagyon újszerû, kis esztétikai értékû reklámra (reklám szövege: Milc shake [turmix].

Az ötletek összekeverésének szépsége. A megjelenés ne tévessze meg: ha összerakjuk a fejünket, akkor a lehetô legnagyszerúbb ötleteket találjuk ki az ön márkája számára.

Lucia Menoncelli webdesigner+Renzo Morocchi grafikus, forrás: http://adsoftheworld.com/media/ print/milc_advertising_milc_shake_lucia_morrocchi)

\section{A konstruktumok megfelelő megfogalmazásának vizsgálata}

A szakirodalom alapján a reklámok esztétikai értéke, újszerúsége, érthetôsége, esetleg kreativitása befolyásolhatja azok múvészi megítélését. A konstruktumok egy része nem egyértelmú az átlagember számára (pl. esztétikai érték, újszerûség), így a konstruktumok megfogalmazásának megfelelô módja a vizsgálatban nem evidens. A korábban leírt elôvizsgálatokban a következô megfogalmazásokat használtuk: mennyire esztétikus, újszerû, érthetô és kreatív.

Az elôvizsgálatokban használt változók esetében alkalmazott Kolmogorov-Szmirnov-próba alapján az esztétikai érték konstruktumra vonatkozó változók eloszlása szignifikáns mértékben $(\alpha=0,05)$ eltért a normál eloszlástól mindkét vizsgálatban (mindkét esetben kerekítve $\mathrm{D}=0,27, \mathrm{p}<0,05)$. Az esztétikusság változóval való összefüggések vizsgálatára Spearman-féle rangkorrelációt alkalmaztuk. Továbbá a kis mintanagyság miatt, ami önmagában valószínútlenebbé teszi a szignifikáns összefüggéseket a tendenciózus összefüggéseket is feltüntetjük.

Az eredmények elemzésekor észleltük, hogy a második elôvizsgálatban a reklámonként számolt mediánja az esztétikusságnak $\rho=0,44$-es Spearman-féle tendenciózus korrelációt mutat az érthetôséggel $(\mathrm{p}<0,1)$, és nem korrelál sem az újszerúséggel, sem a kreativitással. Ugyanitt az újszerûség és a kreativitás nem korrelál az érthetôséggel $(\mathrm{r}=-0,11$ és $\mathrm{r}=0,06 ; \mathrm{ps}>0,1)$, ami a konstruktumokat tekintve szintén meglepó eredmény, figyelembe véve Philips (2003) eredményét. Az érthetôség megítélése valószínúleg a társas kívánatosság által erôsen befolyásolt volt: csak nagyon indokolt esetben vallják be az emberek, ha valami nem érthetô számukra. Ugyanakkor az érthetôség esztétikussággal való szoros korrelációját okozhatja az, hogy az esztétikusság megítélése is 
erôsen befolyásolt a társas kívánatosság által. Összességében a korrelációk arra utaltak, hogy a változók megfogalmazásai nem a mérni kívánt konstruktumokat fejezik ki a vizsgálati személyek számára. Így a konstruktumokat másként fogalmaztuk meg a vizsgálati személyek számára, tesztelve ennek hatását a harmadik elôvizsgálat keretében.

Itt az esztétikai értéket igényes kivitelezésként, az újszerûséget szokatlanságként, az érthetôséget az érthetôség könnyedségeként ítéltettük meg, míg a kreativitást az ötletességként fogalmaztuk meg (lásd bôvebben Balázs és Barkó, 2013).

A harmadik elôvizsgálatban a szokatlanság és ötletesség változók az elvárt módon negatív kapcsolatban állnak az érthetôséggel (rendre $\mathrm{r}=-0,37, \mathrm{p}>0,1$; illetve $\rho=-0,39$, $\mathrm{p}<0,001$ ), így ezek a megfogalmazások valószínúleg jobban lefedik a vizsgálati személyek számára az újszerúség és kreativitás konstruktumokat. Ugyanakkor az igényes kivitelezési mód megfogalmazás ezzel a két konstruktummal jelentósnek mondható lineáris kapcsolatot mutatott (rendre $\rho=0,62, p<0,01$, illetve $\rho=0,8, p<0,001$ ). Azaz úgy tûnik, hogy az igényes kivitelezési mód a korábbinál is jobban a globális megítélést hívja elô. Ugyanakkor egy vizsgálatban (Hagtvedt és mtsai, 2008) két külön faktorba került a szépség és a kivitelezés, ez pedig szintén az adott megfogalmazás ellen szól. Így lehetséges, hogy ebben a kivitelezés igényessége alatt már nemcsak a szépséget, az esztétikai értéket, hanem egy tágabb értelemben vett minôségi jellemzôt értettek.

A fent bemutatott eredmények alapján az esztétikai érték konstruktumára vonatkozóan a megfogalmazás módosítására volt szükség. A reklám szépségének megítélése a társas kívánatosság által befolyásolt változó lehetett volna, ezért a fôvizsgálatban az inger csúnyaságának megítélését kértük. Az érthetôség megítélése helyett a továbbiakban a mennyire könnyedén érthetô megfogalmazást használtuk. Továbbá Hekkert és munkatársai (2003) eredményei amellett szólnak, hogy a prototipikusság és az újszerúség külön dimenziót alkotnak, így külön változóként mértük a prototipikusságot: tipikusságként.

\section{Fövizsgálat}

A fôvizsgálat célja a reklámok múvészi megítélését befolyásoló tényezôk meghatározása; a múvészi jelleg és az ezt meghatározó tényezôk hatásvizsgálata; a kreativitás múvészi megítéléssel és esztétikai értékkel való kapcsolatának tesztelése; és a meggyôzési tudatosság hatásának vizsgálata. A konkrét hipotézisek megegyeznek a korábban feltüntetett hipotézisekkel. A hipotézisvizsgálaton felül azt is vizsgáltuk, hogy vajon az újszerúség-prototipikusság konstruktumok egyazon latens dimenzió egymáshoz képest fordított indikátoraiként múködnek, vagy ezek eltérô módon képesek hatni a múvészi reklámok múvészi jellegének megítélésére és hatásosságára.

\section{Módszer}

A vizsgálati személyeknek egy online kérdôívben elôször 19 print reklámot kellett egyenként megítélniük változók mentén. A reklámok forrása a mellékletben található. A megértést segítendô az angol nyelvú reklámszövegek magyar fordítása is megjelenítésre került a reklámok képe alatt. A vizsgálati személyek a reklámokat abból a 
szempontból értékelték, hogy mennyire tetszik nekik, mennyire tartják figyelemfelkeltônek és hatásosnak, illetve könnyen érthetônek egy tízfokú Likert-skála mentén meghatározva.

Az ingereket a korábban már ismertetett 3x3-as elrendezés mentén (újszerûség x esztétikai érték) választottuk ki. A 9 designcellában a nagyon újszerú-alacsony esztétikai értékú cella kivételével mindenütt 2-2 reklám szerepelt, a szóban forgó cellában az elôvizsgálatban tapasztalt nehézségek miatt három reklám szerepelt.

Ezt követte a demográfiai adatok felvétele, mint a nem, a kor, a végzettség és a jártasság a múvészetek és a reklámok terén. A kérdôív ezen része maszkoló funkciót is betöltött az ezután következô felidézésvizsgálat elôtt.

A következô lépésben a vizsgálati személyeknek három reklámot kellett felidézniük és szövegesen rögzíteniük a korábban látott reklámok közül.

Az kérdőív negyedik részben a kitöltôknek újra értékelniük kellett a reklámokat a múvészi jelleggel összefüggésbe hozható konstuktumok mentén. A következó jellemzôk mérésére került sor tízfokú Likert-skálán: ötletesség, tipikusság, csúnyaság, szokatlanság és a reklám észlelt múvészi volta.

Végül a vizsgálati személyek reklámokkal kapcsolatos általános attitúdjeinek felmérésére került sor. Kilenc állítást kellett tízfokú skálán megítélniük, hogy mennyire tartják magukra nézve jellemzônek. A vizsgálatban használt kérdőív a Bearden és munkatársai (2001) által készített Fogyasztói magabiztosság kérdőív meggyôzési tudatosság skálája alapján készült. Az amerikai populációra kifejlesztett kérdôív állításait a kulturális különbség miatt extrémebbé tettük, illetve a skálát kiegészítettük három itemmel (utolsó három item). A vizsgálatban használt kérdôív állításai:

„Mindig tudom, hogy egy ajánlat mikor »túl szép ahhoz, hogy igaz legyen«." (1);

„Mindig felismerem az ajánlatok megszorító feltételeit is."(2);

„Mindig könnyen megértem a kereskedôk alku stratégiáját.” (3);

„Mindig felismerem a vásárlásra irányuló nyomást.” (4);

„Az eladók vásárlásra ösztönzô trükkjeit mindig átlátom.” (5);

„A reklámokban mindig el tudom különíteni az illúziókat a tényektôl.” (6);

„A reklámok hasznosak.” (7);

„Szeretek reklámokat nézni." (8);

„Igyekszem elkerülni a reklámokat.” (9)

A teljes kérdôívnek két változata készült el. Az elsố verzióban a reklámok random sorrendben kerültek bemutatásra. A második verzió az elsố verzióhoz képest fordított sorrendben tartalmazta a reklámokat, a sorrendi hatás kiküszöbölése érdekében.

A bevezetô instrukciós rész arra vonatkozott, hogy a vizsgálati személynek a továbbiakban reklámokat kell értékelnie, illetve olyan általános demográfiai adatot kellett megadnia, mint a nem, a kor és a végzettség. A bevezetố instrukcióban a válaszok anonim kezelése és kizárólag kutatási célra történố használata is deklarált volt. A kérdôívek kitöltése nagyjából 25 percet vett igénybe. 
Akárcsak az elôzőekben, a vizsgálati személyeket egy közösségi oldalon, személyesen, illetve pszichológushallgatók segítségével toboroztuk. A toborzás instrukciója mindössze arra vonatkozott, hogy reklámokkal kapcsolatos vizsgálatban vehetnek részt. A vizsgálat linkjére való kattintás a vizsgálati személyeket random módon rendelte a kérdôív egyik vagy másik verziójához.

A fôvizsgálat kérdôívét 167 fơ kezdte el kitölteni; 83 fố az egyik verziót, 84 fố a reklámokat tekintve fordított sorrendû verzióját. Maradéktalanul 117 fô töltötte ki a kérdôívet, ebbôl 57-en az egyik verziót és 60 -an a fordított verziót. A végleges mintát alkotó, a kérdôívet hiánytalanul kitöltố személyek közül 98 fố nố volt és 18 fố férfi. Átlagéletkoruk 25,28 év ( $\mathrm{SD}=6,84)$. Közülük 1 fô alapfokú 58 fô középfokú, 57 fô felsôfokú végzettségú. 42 fó jelölte meg, hogy a reklámokkal (25) vagy a múvészetekkel (17) kapcsolatos a foglalkozása. Több vizsgálati személy szóban is beszámolt kétségérôl, hogy vajon helyesen válaszolt-e a jártassággal kapcsolatos kérdésre. Ôk például akkor is igennel válaszoltak, ha apróhirdetéssel kapcsolatos gyakornoki pozícióban dolgoztak, vagy múvészeti orientációjú középiskolába jártak, ami nem árulkodik vizsgálatunk szempontjából a laikusoktól elmélyültebb jártasságról. Így végül az adatok elemzése során az önbevallás alapján jártasabb személyeket nem kezeltük külön csoportként.

\section{Eredmények}

Fontos megjegyezni, hogy bár az eredmények leírása során mindvégig az esztétikai értékre és újszerûségre hivatkozunk, ezek a konstruktumok szakirodalmi megnevezései. A vizsgálati személyeket azonban a reklámok csúnyaságáról és szokatlanságáról kérdeztük. A csúnyaság értékelését fordított itemként kezeljük az esztétikai érték meghatározásához. Azonban az elóvizsgálatok alapján a vizsgálati személyek számára ezek a megnevezések megfelelóek a vizsgálni kívánt konstruktumok megragadásához. Továbbá a reklámok megítélésének mediánjait számoltuk reklámonként, és az így kapott jellemzô viszonyulások összefüggéseit elemeztük.

Az adatelemzés kezdeti lépéseként Kolmogorov-Szmirnov-próbával ellenôriztük a vizsgálatban szereplố változók eloszlásának normalitását, az eredmények alapján $(\alpha=0,05)$ a változók normál eloszlást követnek (Ds<0,27, ps $>0,13)$.

A tipikusság és újszerúség nem különül el az általunk vizsgált populációban (a tipikusság és szokatlanság változókkal vizsgálva). A kettô közötti korreláció értéke nagyon magas $\mathrm{r}=-0,98(\mathrm{p}<0,001)$, és negatív összefüggést mutat. Ebbôl következően, Hekkert és munkatársaitól (2003) eltérốen, jelen esetben egyazon latens dimenzió egymáshoz képest fordított indikátoraiként kezeltük a két változót, és hipotézisvizsgálatot csak a szokatlanságként megnevezett változóra vonatkozóan végeztünk.

Azt vártuk (H1), hogy a múvészi jelleg és az esztétikai érték, illetve újszerúség konstruktumok jelen vizsgálatban használt megfogalmazásai között kapcsolat lesz. A Pearson-féle korreláció alapján az esztétikai érték megítélése kapcsolatban áll a múvészi jelleggel $(r=0,66 ; p<0,001)$, míg az újszerúség nem $(r=0,38 ; p>0,1)$. A múvészi megítélést tehát jobban befolyásolja az esztétikai érték, mint az újszerúség. Ha mind- 
1. táblázat. A mûvészi megítélés bejóslása az esztétikussággal és az újszerûséggel

\begin{tabular}{|l|c|c|c|c|c|c|c|c|}
\hline & $\beta$ & $\mathrm{SE}$ & $\mathrm{t}$ & $\mathrm{p}(\mathrm{t})$ & $\mathrm{F}$ & $\mathrm{df}$ & $\mathrm{R}^{2}$ & $\mathrm{p}$ \\
\hline konstans & $-5,41$ & 1,43 & $-3,77$ & $\mathrm{p}>0,05$ & & & & \\
\cline { 1 - 5 } $\begin{array}{l}\text { esztétikai } \\
\text { érték }\end{array}$ & 0,92 & 0,15 & 6,35 & $\mathrm{p}<0,001$ & \multirow{2}{*}{24,86} & 2,16 & 0,73 & $\mathrm{p}<0,001$ \\
\cline { 1 - 5 } & 0,51 & 0,11 & 4,63 & $\mathrm{p}<0,1$ & & & & \\
\hline
\end{tabular}

két független változót együttesen vizsgáljuk egy többváltozós lineáris regressziós modellben, az újszerüségnek tendenciózus hatása van. A magyarázott variancia 39,6\%, ha az esztétikai érték a modellben az egyetlen függô változó, és 72,61\%-ra nô, ha a lineáris egyenletben az újszerúséget is belevesszük.

Azt vártuk (H2), hogy a múvészi megítélés, illetve ennek meghatározói, azaz az esztétikai érték és az újszerúség kapcsolatban áll az egyes hatásdimenziókkal. A 2. táblázatban összefoglaltuk a mért jellemzôk (mûvészi megitélés, esztétikai érték, újszerûség, érthetôség) és a hatásdimenziók közötti korrelációkat. A nagyszámú összevetés miatt csak az $\alpha=0,001$-es szignifikanciánál szélsốségesebb összefüggéseket tekintjük jelentốsnek, és csak azokat a korrelációkat tüntetjük fel, melyek legalább $\alpha=0,05$-ös szintú kapcsolatot mutatnak, ezeket tendencia jellegúnek tekintjük.

2. táblázat. A hatásdimenziók kapcsolata a múvészi megítéléssel és elemeivel

\begin{tabular}{|l|c|c|c|c|}
\hline & múvészi & esztétikai érték & újszerú & érthetó \\
\hline tetszés & $0,82^{*}$ & $0,67^{*}$ & & \\
\hline figyelem & $0,54^{\mathrm{T}}$ & & $0,74^{*}$ & \\
\hline hatásos & $0,69^{*}$ & & $0,53^{\mathrm{T}}$ & \\
\hline emlékezet & & & & \\
\hline
\end{tabular}

Ahol a * jelentése:p<0,001, a T jelölés jelentése $\mathrm{p}<0,05$.

A hatásdimenziók közül az esztétikai érték a tetszéssel mutatott közvetlen kapcsolatot $(\mathrm{r}=0,67, \mathrm{p}<0,001)$; míg az újszerúség a figyelemfelkeltố képességgel $(\mathrm{r}=0,74$; $\mathrm{p}<0,001)$ és a hatásossággal tendencia jellegú kapcsolatot $(r=0,53 ; \mathrm{p}<0,05)$. Az emlékezeti teljesítménnyel a hatásdimenziók nem függtek össze ( $\mathrm{rs}<0,41 ; \mathrm{ps}>0,05)$. A múvészi jelleg a tetszéssel $(r=0,82 ; \mathrm{p}<0,001)$ és a szubjektíven megítélt hatásossággal $(\mathrm{r}=0,69$; $\mathrm{p}<0,001)$ is magas korrelációt mutatott, ugyanakkor tendencia jelleggel a figyelemfelkeltố képességgel függött össze $(r=0,54 ; \mathrm{p}<0,05)$. Az érthetôség megítélése nem korrelált a hatásdimenziókkal $(\mathrm{p}>0,1)$.

A továbbiakban bemutatott adatelemzések esetén az általában alkalmazott $\alpha=0,05$-es szignifikanciaszintet használjuk és a legalább $\alpha=0,1$-es szintú kapcsolatot tekintjük tendencia jellegúnek.

A többváltozós lineáris regresszió analízis eredményei alapján az érthetôségnek is szerepe van a hatásosságban. Az alábbiakban a vizsgált hatáselemenként haladva mutatjuk be a szignifikáns regressziós modelleket.

A 3. és a 4. táblázatban megjelenített modellek eredményei alapján a tetszésben szerepet játszik éppúgy a mûvészi jelleg, mint annak elemei (újszerúség, esztétikai érték). 
3. táblázat. A tetszés bejóslása a múvészi megítéléssel és az érthetôséggel

\begin{tabular}{|l|c|c|c|c|c|c|c|c|}
\hline & $\beta$ & $\mathrm{SE}$ & $\mathrm{t}$ & $\mathrm{p}(\mathrm{t})$ & $\mathrm{F}$ & $\mathrm{df}$ & $\mathrm{R}^{2}$ & $\mathrm{p}(\mathrm{F})$ \\
\hline konstans & 0,20 & 0,81 & 0,25 & $\mathrm{p}>0,1$ & & & & \\
\cline { 1 - 7 } múvészi & 0,64 & 0,08 & 8,17 & $\mathrm{p}<0,001$ & \multirow{2}{*}{39} & \multirow{2}{*}{2,16} & \multirow{2}{*}{0,81} & $\mathrm{p}<0,001$ \\
\cline { 1 - 6 } érthetó & 0,36 & 0,10 & 3,77 & $\mathrm{p}<0,01$ & & & & \\
\hline
\end{tabular}

4. táblázat. A tetszés bejóslása az esztétikai megítéléssel, az újszerúséggel és az érthetôséggel

\begin{tabular}{|c|c|c|c|c|c|c|c|c|}
\hline & $\beta$ & $\mathrm{SE}$ & $\mathrm{t}$ & $p(t)$ & $\mathrm{F}$ & $\mathrm{df}$ & $\mathrm{R}^{2}$ & $p(F)$ \\
\hline konstans & $-5,67$ & 0,93 & $-6,08$ & $\mathrm{p}<0,001$ & \multirow{4}{*}{54,31} & \multirow{4}{*}{3,15} & \multirow{4}{*}{0,90} & \multirow{4}{*}{$\mathrm{p}<0,001$} \\
\hline esztétikai érték & 0,64 & 0,07 & 9,45 & $\mathrm{p}<0,001$ & & & & \\
\hline újszerú & 0,50 & 0,06 & 8,75 & $\mathrm{p}<0,001$ & & & & \\
\hline érthetô & 0,52 & 0,08 & 6,36 & $\mathrm{p}<0,001$ & & & & \\
\hline
\end{tabular}

A tetszés esetében az elsô modellben a múvészi jelleg, míg a másodikban az esztétikai érték a legnagyobb súlyú változó. Ahogyan a 7. ábrán látható, a tetszésértékek jól illeszkednek az esztétikai értékkel és újszerûséggel meghatározott modellre.

Az általunk elvárt, és a lineáris regresszió elemzések által támogatott modell a tetszésre vonatkozóan a 8 . ábrán látható. Útmodellel megvizsgálva a teljes modell nem illeszkedik $\left(\chi^{2}=25,76 ; \mathrm{df}=6, \mathrm{p}<0,001 ; \mathrm{RMSEA}=0,43 ; \mathrm{SRMR}=0,21\right)$. Viszont az érthetôség tényezôt elhagyva (szaggatott szürke nyíllal jelölve az ábrán) egy jobban illeszkedô

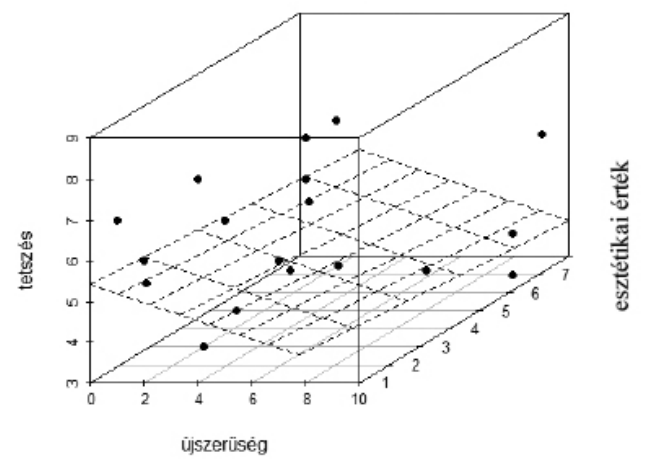

7. ábra. A tetszési értékek illeszkedése az újszerûség és esztétikai érték által meghatározott modellre

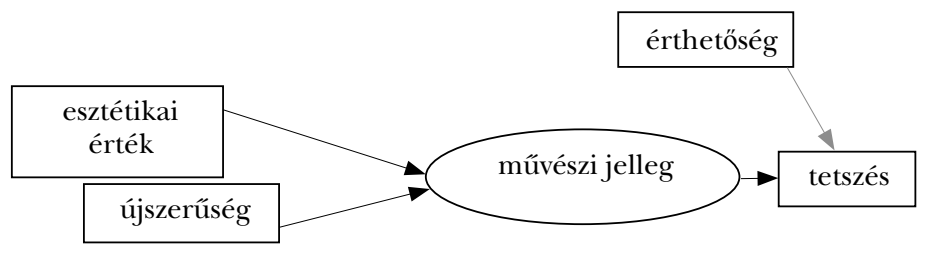

8. ábra. A múvészi jelleg és dimenzióinak hatása a tetszésre 
modellt kapunk $\left(\chi^{2}=4,66 ; \mathrm{df}=3 ; \mathrm{p}>0,1 ; \mathrm{RMSEA}=0,18 ; \mathrm{SRMR}=0,18\right)$. Ugyan a kis mintanagyság miatt messzemenô következtetéseket nem vonhatunk le az útmodell alapján.

A hatásosság esetében az eredmények az 5. és a 6. táblázatban láthatóak. Az elsô lineáris regressziós modellben a múvészi jelleg, a második modellben az újszerúség és az érthetôség is jelentôs szerepet játszanak a hatásosság megítélésében. A hatásosság becslésének értékei valamivel kevésbé jól illeszkednek az esztétikussággal és újszerúséggel meghatározott modellre, mint ahogy ezt a tetszés esetében láttuk (9. ábra), de az illeszkedés így is megfeleló.

Az általunk elvárt és a lineáris regressziós modellek által támogatott összegzô modell a hatásosságra vonatkozóan a 10. ábrán látható. Útmodellel megvizsgálva a teljes modell nem illeszkedik $\left(\chi^{2}=28,44 ; \mathrm{df}=6, \mathrm{p}<0,001\right.$; RMSEA=0,46; SRMR=0,21).Viszont az érthetôség tényezốt elhagyva (szaggatott szürke nyíllal jelölve az ábrán) egy jobban illeszkedô modellt kapunk $\left(\chi^{2}=4,51 ; \mathrm{df}=3 ; \mathrm{p}>0,1\right.$; RMSEA=0,17; SRMR=0,19). Továbbra is igaz, hogy a kis mintanagyság miatt óvatosnak kell lennünk az útmodell értelmezésekor.

A múvészi jelleg szerepet játszik a reklám figyelemkeltô képességének megítélésében $\left(\beta=0,42 ; \mathrm{SE}=0,16 ; \mathrm{t}=2,62 ; \mathrm{p}<0,05 ; \mathrm{R}^{2}=0,22\right)$. Az érthetôség ebben az esetben nem befolyásolja a figyelemfelkeltố képességet. A figyelemfelkeltés bejóslására vonatkozó másik modell a 7. táblázatban látható. A reklám figyelemfelkeltô képességének megítélése összefügg még az újszerúséggel és az érthetôséggel is.

5. táblázat. A hatásosság bejóslása a múvészi megítéléssel és az érthetôséggel

\begin{tabular}{|l|c|c|c|c|c|c|c|c|}
\hline & $\beta$ & $\mathrm{SE}$ & $\mathrm{t}$ & $\mathrm{p}(\mathrm{t})$ & $\mathrm{F}$ & $\mathrm{df}$ & $\mathrm{R}^{2}$ & $\mathrm{p}(\mathrm{F})$ \\
\hline konstans & $-0,20$ & 1,10 & $-0,18$ & $\mathrm{p}>0,05$ & \multirow{3}{*}{11,7} & \multirow{2}{*}{2,16} & \multirow{3}{*}{0,53} & $\mathrm{p}<0,001$ \\
\cline { 1 - 6 } múvészi & 0,46 & 0,11 & 4,36 & $\mathrm{p}<0,001$ & & \\
\cline { 1 - 6 } érthetố & 0,26 & 0,13 & 2,00 & $\mathrm{p}<0,1$ & & & & \\
\hline
\end{tabular}

6. táblázat. A hatásosság bejóslása az esztétikai megítéléssel, az újszerúséggel és az érthetôséggel

\begin{tabular}{|c|c|c|c|c|c|c|c|c|}
\hline & $\beta$ & SE & $\mathrm{t}$ & $p(t)$ & $\mathrm{F}$ & $\mathrm{df}$ & $\mathrm{R}^{2}$ & $\mathrm{p}(\mathrm{F})$ \\
\hline konstans & $-5,20$ & 1,19 & $-4,37$ & $\mathrm{p}<0,001$ & \multirow{4}{*}{21,78} & \multirow{4}{*}{3,15} & \multirow{4}{*}{0,78} & \multirow{4}{*}{$\mathrm{p}<0,001$} \\
\hline $\begin{array}{l}\text { esztétikai } \\
\text { érték }\end{array}$ & 0,27 & 0,09 & 3,12 & $\mathrm{p}<0,01$ & & & & \\
\hline újszerú & 0,54 & 0,07 & 7,43 & $\mathrm{p}<0,001$ & & & & \\
\hline érthetô & 0,55 & 0,10 & 5,30 & $\mathrm{p}<0,001$ & & & & \\
\hline
\end{tabular}

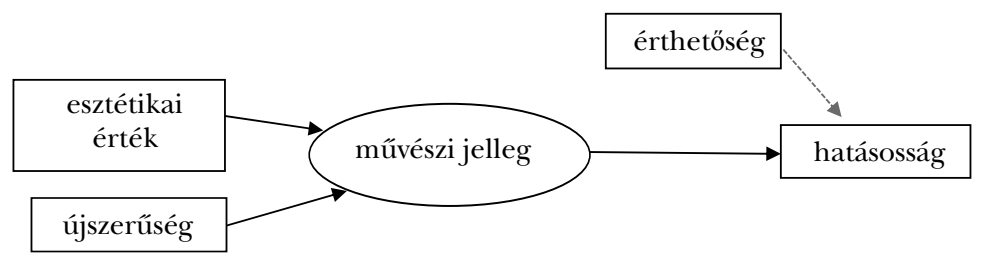

9. ábra. A mûvészi jelleg és dimenzióinak hatása a hatásosságra 


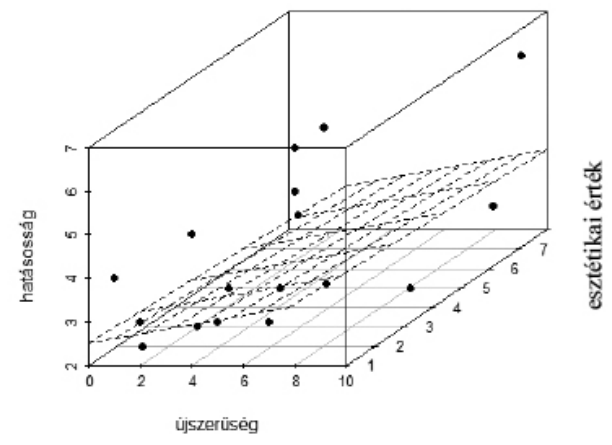

10. ábra. A hatásosság értékeinek illeszkedése az újszerúség és esztétikai érték által meghatározott modellre

7. táblázat. A figyelemfelkeltés megítélésének bejóslása az újszerúséggel és az érthetôséggel

\begin{tabular}{|l|c|c|c|c|c|c|c|c|}
\hline & $\beta$ & $\mathrm{SE}$ & $\mathrm{t}$ & $\mathrm{p}(\mathrm{t})$ & $\mathrm{F}$ & $\mathrm{df}$ & $\mathrm{R}^{2}$ & $\mathrm{p}(\mathrm{F})$ \\
\hline konstans & $-1,44$ & 1,09 & $-1,32$ & $\mathrm{p}>0,1$ & & & & \\
\cline { 1 - 5 } újszerú & 0,69 & 0,08 & 8,83 & $\mathrm{p}<0,001$ & \multirow{2}{*}{39,32} & 2,16 & \multirow{2}{*}{0,81} & $\mathrm{p}<0,001$ \\
\cline { 1 - 5 } érthetố & 0,58 & 0,11 & 5,20 & $\mathrm{p}<0,001$ & & & & \\
\hline
\end{tabular}

A reklámok felidézési gyakoriságát egyedül a reklám múvészi értéke jósolja be, azonban csekély mértékben $\left(\beta=2,18 ; \mathrm{SE}=1,21 ; \mathrm{t}=1,80 ; \mathrm{p}<0,1 ; \mathrm{R}^{2}=0,11\right)$. A lineáris regressziós modellek eredményei alapján a második hipotézis tartható, bizonyos megkötésekkel. Minden hatáselem bejósolható a múvészi megítéléssel. A felidézési gyakoriságon kívül minden múvészi jelleget meghatározó tulajdonság is részt vesz a hatásosság dimenziók valamelyikének a megítélésében. Továbbá az érthetôség kismértékben segíti a hatásosság bejóslását az esetek többségében. Azonban a reklámfelidézést kismértékben tudjuk ezekkel a jellemzókkel elôre jelezni.

Feltételeztük, hogy aki hiszi, hogy a meggyôzési helyzetekben jobban kiismeri magát, az alacsonyabbra értékeli a reklámok hatékonyságát. A hipotézis vizsgálata elôtt a kérdôív megbízhatóságát vizsgáltuk. A Bearden és munkatársai (2001) által kifejlesztett, kissé extrémebbé tett itemekbôl álló mérôeszköz megbízhatósága megfelelô, az általunk hozzátett itemek nem javítják azt, ezeket nem vesszük figyelembe a pontszám kiszámításakor. A mérôeszköz megbízhatósági mutatója megegyezik az eredeti mérốeszköz megbízhatóságával (Cronbach $\alpha=0,80$ ). A meggyôzési tudatosság a legtöbb hatásosságdimenzióra számolt átlagos értékeléssel nem mutatott kapcsolatot a Pearson-féle korrelációval mérve $(\mathrm{p}>0,1)$. A figyelemfelkeltô képességnek volt gyenge, tendenciózus kapcsolata a meggyôzési tudatossággal $(r=0,15 ; \mathrm{p}<0,1)$. Ezen kívül, a reklámok megítélését tekintve, az esztétikai érték megítélése van még hasonlóan mérsékelt kapcsolatban a meggyőzési tudatossággal $(\mathrm{r}=0,23 ; \mathrm{p}<0,05)$. Bár ezeket az eredményeket óvatosan kell kezelnünk, de arra utalnak, hogy a magabiztosabb fogyasztó valamivel pozitívabban értékeli a reklámok egyes aspektusait.

Feltételeztük a kreativitás összefüggését az újszerúséggel, esztétikai értékkel (H4). A Pearson-féle korreláció alapján a kreativitás csak az újszerúséggel mutatott kapcso- 
8. táblázat. A kreativitás megítélésének bejóslása a múvészi megítélést meghatározó tényezôkkel és az érthetôséggel

\begin{tabular}{|c|c|c|c|c|c|c|c|c|}
\hline & $\beta$ & $\mathrm{SE}$ & $\mathrm{t}$ & $p(t)$ & $\mathrm{F}$ & $\mathrm{df}$ & $\mathrm{R}^{2}$ & $p(F)$ \\
\hline konstans & $-0,11$ & 0,80 & $-0,13$ & $\mathrm{p}>0,1$ & \multirow{4}{*}{105,7} & \multirow{4}{*}{3,15} & \multirow{4}{*}{0,95} & \multirow{4}{*}{$\mathrm{p}<0,001$} \\
\hline újszerú & 0,95 & 0,06 & 16,70 & $\mathrm{p}<0,001$ & & & & \\
\hline $\begin{array}{l}\text { esztétikai } \\
\text { érték }\end{array}$ & 0,38 & 0,07 & 5,78 & $\mathrm{p}<0,001$ & & & & \\
\hline érthetô & 0,27 & 0,08 & 3,46 & $\mathrm{p}<0,01$ & & & & \\
\hline
\end{tabular}

latot $(\mathrm{r}=0,89 ; \mathrm{p}<0,001)$. A többváltozós lineáris regressziós modell (8. táblázat) alapján azonban a múvészi jelleg alkotóelemei, valamint az érthetôség is szerepet játszanak a kreativitás magyarázatában. Természetesen az újszerúség ragadja meg a magyarázott variancia legnagyobb hányadát $\left(R^{2}=0,79\right)$, az esztétikusság $\left(+R^{2}=0,12\right)$, és az érthetôség $\left(+\mathrm{R}^{2}=0,04\right)$ csak kismértékben növeli a magyarázott varianciát.

A reklám múvészi jellegének és kreativitásának megítélése jól korrelál egymással $(\mathrm{r}=0,63 ; \mathrm{p}<0,01)$. Ugyanakkor a kreativitás megítélése a múvészi megítélés bejóslását nem segíti, ha a korábbi múvészi megítélést meghatározó tényezôkkel együtt kerül egy többváltozós regressziós modellbe $(\mathrm{p}>0,1)$.

\section{DISZKUSSZIÓ}

A tanulmány célja a múvészi reklámokat meghatározó jellemzók, és ezek hatásának, illetve magának a múvészi jelleg hatásosságának vizsgálata volt egy több lépésbôl álló vizsgálatsorozat segítségével. A vizsgálat során hangsúlyt fektettünk a laikus befogadók szakértôktôl eltérố nézôpontjára. Az elôvizsgálatok a laikusok reklámok múvészi megítélésének vizsgálatát; a vizsgálat szempontjából a releváns konstruktumok hétköznapi megnevezésének feltárását; illetve az ingerszelekciót szolgálták.

A múvészi reklámokra vonatkozó szakirodalmak alapján a reklámok múvészi voltának meghatározója a reklámok esztétikai értéke (Halász, 2006; Hagtvedt és Patrick, 2008) és újszerúsége (pl. Berlyne, 1971). A fókuszcsoportos elôvizsgálatokban ezek a szempontok szintén felmerültek. A fôvizsgálatban mindkét konstruktum elôrejelzôként szerepelt a múvészi megítélést bejósló többváltozós lineáris regressziós modellben, ugyanakkor az esztétikai érték szerepe egyértelmúen nagyobb. Eredményeink hasonlóak Hagtvedt és munkatársainak (2008) múvészi ingerekre vonatkozó eredményéhez, ahol az ingerek értékelésére a két jellemzô által meghatározott külön úton hat. Ugyanakkor fontos megjegyezni, hogy az esztétikai értéken és újszerúségen kívül még lehet más jellemzó is, ami a reklámok múvészi voltát meghatározza. Feltételezésünk szerint például a fókuszcsoportos interjúk alkalmával felmerült szempontok közül a szimbolikus jelleg lehet az, ami befolyással bírhat még a múvészi megítélésre.

A múvészi reklámok hatásosságát vizsgálva a különbözô jellemzôk eltérô súllyal szerepeltek a hatásosság egyes dimenzióinak bejóslásában. Az összefüggések feltárása alapvetôen lineáris modellek alapján történt. Az adatok alapján a tetszést befolyá- 
solja a múvészi érték megítélése, a mûvészi megítélést meghatározó tényezôk közül pedig inkább a reklám esztétikai értékének van hatása. A szubjektíven értékelt hatásosságra is befolyással van a múvészi jelleg, a múvészi jelleget meghatározó tényezók közül pedig az újszerûség szerepe válik meghatározóbbá. A vizsgálati személyek által megítélt figyelemfelkeltô jellegre a reklám múvészi jellege, illetve az újszerûség és érthetôség hat. A reklámok felidézése egyedül a reklám múvészi jellegével állt gyenge összefüggésben. Ennek számos oka lehet, ilyen többek között a kevés vizsgált reklám és kisszámú vizsgálati személy, aki egyáltalán felidézett reklámokat. Ugyanakkor a reklámfelidézésben valószínúleg jobban kifejezésre jut a téma iránti involváltság, motiváció a befogadásra, így kevéssé tudjuk a felidézést a vizsgált elemek alapján bejósolni. A hatásosságvizsgálatok során, a felidézéstôl eltekintve, mindenütt (kisebb-nagyobb) szerepet játszott az újszerúség, és az újszerúbb megközelítés hatásosabb, pozitívabb megítéléshez vezetett. Az eredmények alapján az érthetôség a reklámok hatásosságában játszik némi szerepet, de nem játszik szerepet a reklámok múvészi jellegének megítélésében. Ez megerósíti Philips (2003) álláspontját, miszerint az érthetôségnek a hatásban van szerepe.

A kreativitás konstruktuma jól elkülönül a vizsgálat alapján a múvészi megítélés konstruktumától. Míg a reklámok múvészi jellegének megítélésében az esztétikai értéknek, addig a kreativitás modelljében az újszerûségnek van nagyobb szerepe, az esztétikai érték csak másodlagos. Ugyanakkor az adatok alapján a fogyasztók számára az esztétikai érték a kreativitás része, legalábbis esetünkben hatással volt a kreativitás megítélésére. Ez megerôsíti a Burroughs és munkatársai (2008) által leírt háromdimenziós kreativitás fogalmat és azokat a forrásokat, melyek a kreativitásnak esztétikai értéket vagy múvészi jelleget is tulajdonítottak (Lehnert és mtsai, 2013; Reinartz és Saffert, 2013; Sasser és mtsai, 2013; West és mtsai, 2013).

Jelen vizsgálatban a hatásosság megítélését nem befolyásolta a fogyasztók meggyôzési tudatossága. Ennek a konkrét reklámokra vonatkozó attitúdtôl sokkal általánosabb attitûdnek a hatása egyedül az esztétikai megítélés esetében, kismértékben volt kimutatható. Ezek az eredmények ellentmondanak Bearden és munkatársai (2001) feltételezésének, miszerint a negatívabb attitûddel rendelkezókre a reklámok kevésbé hatnak. Magyarázhatja az adatokat az, hogy a múvészi reklámok esetében általában elterelôdik a figyelem a reklám meggyôzô szándékáról. Bár Kirmani és Zhu (2007) a feldolgozás mélységétôl függetlenül azt találták, hogy a vizsgálati személyek szisztematikusan megközelítô vagy védekezô módon reagálnak a meggyôzési helyzetekben. Esetleg a vizsgálati csoportunk nem volt eléggé heterogén a meggyôzési tudatosság jellemzóit tekintve.

A vizsgálat empirikusan demonstrálta a nyomtatott reklámok múvészi jellegének fogyasztókra gyakorolt pozitív hatását. Ez a marketingszakemberek számára is érdekes lehet, még akkor is, ha nem komplex marketingstratégiát, hanem a marketingmix egyetlen elemét, a reklámokat és azoknak is csak a nyomtatott verzióját vizsgáltuk. Az adatok alátámasztják az esztétikai érték és újszerúség szerepét a múvészi reklámok hatásosságában. A vizsgálat eredményei demonstrálják a reklámok kreatív és múvészi megítélésének elkülönülését. Eszerint nem egybemosható a két megközelítés, elkülönülố meggyôzési stratégiának tekinthetjük óket. 
Ugyanakkor az elôvizsgálatok eredményei felhívják a figyelmet annak fontosságára, hogy a konstruktumok a laikusoknak megfelelô módon kerüljenek megfogalmazásra hasonló jellegú vizsgálatokban.

Célszerú lenne újabb reklámkutatásokban több reklámot bevonva vizsgálni az itt felvetett hipotéziseket, vagy alternatív módszertant alkalmazni az eredmények validitásának erôsítése végett. A hasonló vizsgálatok tervezését nehezíti, hogy nagyszámú reklám és/vagy nagyszámú reklámra vonatkozó kérdés esetén a kérdôív kitöltésének ideje meghosszabbodik, és emiatt sok vizsgálati személy lemorzsolódik, ezt játékos kitöltési felülettel vagy anyagi kompenzációval lehetne ellensúlyozni.

Alternatív kutatási irányvonal a területen az attitûdváltozásra fókuszáló, illetve a viselkedés elôrejelzését célzó mérések alkalmazása. Továbbá érdemes lenne a vizsgálati személyek múvészetek iránti fogékonyságát is figyelembe venni a különbözó jellemezôkkel bíró múvészi reklámok hatásosságát vizsgálva.

A múvészi reklámok, illetve a múvészi elemeket tartalmazó meggyôzô üzenetek hatásosságának pszichológiai vizsgálata tehát még számos lehetôséget rejt magában. Jelen vizsgálat a témának egy empirikus megközelítési lehetôségét demonstrálta a fogyasztói megközelítést hangsúlyosan figyelembe véve.

\section{KÖSZÖNETNYILVÁNÍTÁS}

Jelen kutatást a Debreceni Egyetem támogatta (RH/751/2015). Továbbá a publikáció elkészítését a TÁMOP-4.2.2/B-10/1-2010-0024 számú projekt támogatta. A projekt az Európai Unió támogatásával, az Európai Szociális Alap társfinanszírozásával valósult meg.

\section{IRODALOM}

Ajzen, I. (1991). The theory of planned behavior. Organizational Behavior in Human Decision Processes, 50, 179-211.

Auble, P., Franks, J., \& Soraci, S. (1979). Effort toward comprehension: Elaboration or aha!? Memory E Cognition, 7, 426-434.

Balázs K., \& Barkó M. (2013). Az újszerúség, kreativitás, esztétikusság és érthetôség kapcsolata reklámvizsgálatokban. In Münnich Á. (szerk.), Pszichológiai kutatások - Debreceni Egyetem Pszichológia Doktori Program (pp. 61-73). Debrecen: Debreceni Egyetemi Kiadó.

Bearden, W. O., Hardesty, D. M., \& Rose, R. L. (2001). Consumer self-confidence: Refinements in conceptualization and measurement. Journal of Consumer Research, 28(1), 121-134.

Berlyne, D. E. (1971). Aesthetics and psychobiology. New York: Appleton-Century-Crofts.

Berlyne, D. E. (1994). A kollatív változók. In Farkas A., \& Gyebnár V. (szerk.), Vizuális múvészetek pszichológiája 1. (pp. 23-50). Szöveggyújtemény. Budapest: Nemzeti Tankönyvkiadó.

Benesch, H. (1994). SH atlasz: Pszichológia. Budapest: Springer Hungária.

Burroughs, J. E., Moreau C. P., \& Mick, D. G. (2008). Toward a psychology of consumer creativity. In C. P. Haugtvedt, P. M. Herr, \& F. R. Kardes (Eds.), Handbook of consumer psychology (pp. 1011-1038). New York: Taylor and Francis Group.

Campbell, M. C., \& Kirmani, A. (2008). I know what you're doing and why you're doing it: the use of the persuasion knowledge model in consumer research. In C. P. Haugtvedt, P. Herr, 
\& F. Kardes (Eds.), The handbook of consumer psychology (pp. 549-571). New Jersey: Lawrence Erlbaum.

Cho, C. H. \& Cheon, H. J. (2004). Why do people avoid advertising on the internet? Journal of Advertising, 33, 89-97.

Chupnik, G. C., \& Gebotys, R. J. (1997). A jelentés keresése a múalkotásban: értelmezési stílusok és a minőség megítélése. In Farkas A. (szerk.), Vizuális müvészetek pszichológiája 2. Szöveggyújtemény (pp. 173-189). Budapest: Nemzeti Tankönyvkiadó.

Cropley, D. H., \& Cropley, A. J. (2011). Aesthetics and creativity. In M. A. Runco, \& S. R. Pritzker (Eds.), Encyclopedia of Creativity (2nd ed., pp. 24-28). New York: Academic Press.

Dahlén, M., Rosengren, S., \& Törn, F. (2008). Advertising creativity matters. Journal of Advertising Research, 48(3), 392-403.

Farkas, A. (2003). Az esztétikai itélet - Múvészetpszichológiai modellek. Budapest: Nemzeti Tankönyvkiadó.

Fishbein, M. \& Ajzen, I. (2010). Predicing and changing behavior: The reasoned action aproach. New York: Psychology Press.

Friestad, M. \& Wright P. (1994). The persuasion knowledge model: How people cope with persuasion attempts. Journal of Consumer Research, 21, 1-31.

Guo, W., \& Main, K. (2014). Can persuasion knowledge change preferred persuasion based on self-construal? In J. Cotte, \& S. Wood (Eds.), Advances in consumer research [Volume 42.] (pp. 498-501). Duluth, MN : Association for Consumer Research.

Hagtvedt, H., \& Patrick, V. M. (2008). Art infusion: The influence of visual art on the perception and evaluation of consumer products. Journal of Marketing Research, 45, 379-389.

Hagtvedt, H., Hagtvedt, R., \& Patrick, V. M. (2008). The perception and evaluation of visual Art. Empirical Studies Of The Arts, 26(2), 197-218.

Halász L. (2006). Múvészetpszichológia. In Bagdy E., \& Klein S. (szerk.), Alkalmazott pszichológia (pp. 187-203). Budapest: Edge 2000.

Haley, R. I., \& Baldinger, A. L. (2000). The ARF copy research validity project. Journal of Advertising Research, 40, 114-134.

Hardesty, D. M., Bearden, W. O., \& Carlson, J. P. (2007). Persuasion knowledge and consumer reactions to pricing tactics, Journal of Retailing, 83(2), 199-210.

Hekkert, P., Snelders, D., \& van Wieringen, P. C. W. (2003). 'Most advanced, yet acceptable': Typicality and novelty as joint predictors of aesthetic preference in industrial design. British Journal of Psychology, 94, 111-124.

Hetsroni, A., \& Tukachinsky, R. H. (2005). The use of fine art in advertising: A survey of creatives and content analysis of advertisements. Journal of Current Issues and Research in Advertising, $27(1), 93-107$.

Hoegg, J., \& Alba, J. (2008). A role for aesthetics in consumer psychology. In C. P. Haugtvedt, P. M. Herr, \& F. R. Kardes (Eds.), Handbook of consumer psychology (pp. 733-754). New York: Taylor and Francis Group.

Huettl, V., \& Gierl, H. (2012). Visual art in advertising: The effects of utilitarian vs. hedonic product positioning and price information. Marketing Letters, 23, 893-904.

Joy, A., \& Sherry, J. F. (2003). Speaking of art as embodied imagination: A multisensory approach to understanding aesthetic experience. Journal of Consumer Research, 30, 259-282.

Kirmani, A. \& Zhu, R. (2007). Vigilant against manipulation: The effect of regulatory focus on the use of persuasion knowledge. Journal of Marketing Research, 44, 688-701.

Lehnert, K. Till, B. D., \& Carlson, B. D. (2013). Advertising creativity and repetition - Recall, wearout and wearin effects. International Journal of Advertising, 32(2), 211-231.

Martindale, C., Moore, K., \& Borkum, J. (1990). Aesthetic preference: Anomalous findings for Berlyne's psychobiological theory. The American Journal of Psychology, 103(1), 53-80. 
Martindale, C., Moore, K., \& West, A. (1997). A tipikusság, az újdonság és az ismételt ingerbemutatás viszonya a preferenciaítéletekhez. In Farkas A. (szerk.), Vizuális múvészetek pszichológiája 2. Szöveggyújtemény (pp. 83-92). Budapest: Nemzeti Tankönyvkiadó.

McAlister, A. R, \& Cornwell, T. B. (2009). Preschool children's persuasion knowledge: The contribution of Theory of Mind. Journal of Public Policy E Marketing, 28(2), 175-185.

Mehta, A., \& Purvis, S. C. (1994). Evaluating advertising effectiveness through advertising response modelling (ARM). Presented at the 1994 Advertising and Consumer Psychology Conference, Minneapolis, MN, May 13-14, 1994. Letöltve: http://www.uwcentre.ac.cn/hhu/ wp-content/uploads/2011/03/evaluatingadfs.pdf

Obermiller, C., \& Sawyer, A. G. (2011). The effects of advertisement picture likeability on information search and brand choice. Marketing Letters, 22, 101-113.

Petty, R. E., \& Cacioppo, J. T. (1981). Attitudes and persuasion: Classic and contemporary approaches. Dubuque, Iowa: Wm. C. Brown.

Petty, R. E., \& Cacioppo, J. T. (1986). Communication and persuasion: Central and peripheral routes to attitude change. New York: Springer-Verlag.

Phillips, B. J. (2003). Understanding visual methaphor in advertising. In L. M. Scott, \& R. Batra (Eds.), Persuasive imagery (pp. 297-310). New York: Routlege.

Reinartz, W., \& Saffert, P. (2013). Creativity in advertising: When it works and when it doesn't. Harvard Business Review, 91(6), 106-112.

Sas I. (2006). Reklám és pszichológia. Budapest: Kommunikációs Akadémia Könyvtár.

Sasser, S. L., Koslow, S., \& Kilgour, M. (2013). Matching creative agencies with results-drivenmarketers: Do clients really need highly creative advertising? Journal of Advertising Research, 53(3), 297-312.

Speck, P. S., \& Elliott, M. T. (1997). Predictors of advertising avoidance in print and broadcast media. Journal of Advertising, 26, 61-76.

Till, B. D., \& Baack, D. W. (2005). Does creative advertising matter? Journal of Advertising, 34(3), $47-57$.

Törő́csik M. (2007). Vásárlói magatartás. Budapest: Akadémiai Kiadó.

Veerkumar, V., \& Jaiswal, N. (2015). Impact of televison advertisement on children's pester power and the purchases made for them in the family. Hamburg: Anchor Academic Publishing.

West, D., Caruana, A., \& Leelapanyalert, K. (2013). What makes win, place, or show? - Judging creativity in advertising at award shows. Journal of Advertising Research, 53(3), 324-338.

West, D. C., Kover, A. J., \& Caruana, A. (2008). Practitioner and consumer view of advertising creativity - same concept, different meaning? Journal of Advertising, 37(4), 35-45.

Whitfield, T. W. A. (2000). Beyond prototypicality: Toward a categorical-motivation model of aesthetics. Empirical Studies of the Arts, 18, 1-11.

Wright, P., Friestad, M., \& Boush, M. (2005). The development of marketplace persuasion knowledge in children, adolescents, and young adults, Journal of Public Policy E Marketing, 24(2), 222-233. 


\title{
INVESTIGATING THE DIMENSIONS AND EFFECT OF ARTISTIC ADVERTISEMENTS
}

\author{
BALÁZS, KATALIN - BARKÓ, MÁRIA
}

Background and aims: The main goal of this study is to investigate artistic advertisements empirically. More precisely, the main goal is the investigation of the effectiveness of artistic advertisements and that of their components revealed in the relevant literature and by prior consumer assessments.

Method: The main study was conducted based on the outcomes of focus group discussions $(N=6)$ and questionnaire based pilot studies ( $N=47$ and $N=43)$. The pilot studies served several purposes: gathering advertisement stimuli that were assessed artistic by consumers; collecting information about consumers' views on artistic advertisements; examining the proper wording of the relevant constructs for participants; and stimuli selection. In both questionnaire studies, 27 advertisements were assessed by the participiants. The main study was conducted via online questionnaire. Participants $(N=117)$ assessed 19 advertisements regarding their effectiveness (preference, ability to draw attention, effectiveness) and descriptive features (lucidity, novelty, creativity, aesthetic value, artistic value). Besides, advertisement recall was also measured. Furthermore, the participants' persuasion knowledge was also measured.

Results: Based on the empirical data, novelty and aesthetic value are salient dimensions of artistic advertisements, while lucidity also plays a role in the effectiveness of artistic advertisements. Beyond these features, creativity does not improve the predictions of the assessment of artistic value. The assessed artistic value of advertisements and its dimensions determine several dimensions of effectiveness, such as preference; assessment of the ability to draw attention; and assessment of impact; but does not really affect recall. Furthermore, based on the results, examinees' persuasion knowledge does not play a significant role in effectiveness.

Conclusions: The empirical data support the application of artistic design in advertising. Besides, the major elements determining artistic assessment are novelty and aesthetic value of advertisements.

Key words: artistic advertisement, effect of advertisement, novelty, aesthetic value, creativity, persuasion knowledge

\section{MELLÉKLET}

http://adsoftheworld.com/media/print/milc_advertising_milc_shake_lucia_morrocchi http://adsoftheworld.com/media/print/mcdonalds_tiffany

http:/ / dijnyertes.hu/kep.php?f=1350

http://dijnyertes.hu/?id=530

http://adsoftheworld.com/media/print/disquedenuncia_domestic_violence_couple http://adsoftheworld.com/media/print/iluminar_ballerina

http://adsoftheworld.com/media/print/mira_guide_dog_association_girl

http://adsoftheworld.com/media/print/kia_pro_ceed_gt_straight_corners_1

http://adsoftheworld.com/media/print/gillette_fusion_proglide_balloon

http://adsoftheworld.com/media/print/horlicks_nutribic_biscuits_docs

http://adsoftheworld.com/media/print/handy_andy_mirror

http://adsoftheworld.com/media/print/walgreens_beauty_trendsetters_showstoppers

http://adsoftheworld.com/media/print/exito_water_green_onion

http://kontar.blog.hu/2009/09/28/antivakarin 
https: / www.facebook.com/photo.p?fbid=478311462248313\&set=pb.443644602381666.-

2207520000.1373372020.\&type $=3 \&$ theater

http://adsoftheworld.com/media/print/chupa_chups_now_with_gum_2

http://www.coloribus.com/adsarchive/prints/tag-heuer-watches-tag-heuer-10607855/

http://adoholik.com/wp-content/uploads/2009/11/dolce-gabbana.jpg

http://dresscodeemlyon.files.wordpress.com/2011/04/chanelaw0910ad01.jpg 